February 2018

\title{
Murky Projects and Uneven Information Policies: A Case Study of the Psychological Strategy Board and CIA
}

Susan Maret

San Jose State University, drsmaret@gmail.com

Follow this and additional works at: https://scholarworks.sjsu.edu/secrecyandsociety

Part of the American Politics Commons, Communication Commons, Public Affairs, Public Policy and Public Administration Commons, and the Theory, Knowledge and Science Commons

\section{Recommended Citation}

Maret, Susan. 2018. "Murky Projects and Uneven Information Policies: A Case Study of the Psychological Strategy Board and CIA." Secrecy and Society 1(2). https://doi.org/10.31979/ 2377-6188.2018.010206 https://scholarworks.sjsu.edu/secrecyandsociety/vol1/iss2/6

This Article is brought to you for free and open access by the School of Information at SJSU ScholarWorks. It has been accepted for inclusion in Secrecy and Society by an authorized administrator of SJSU ScholarWorks. For more information, please contact scholarworks@sjsu.edu.

\section{(c) (1)}

This work is licensed under a Creative Commons Attribution 4.0 License. 


\title{
Murky Projects and Uneven Information Policies: A Case Study of the Psychological Strategy Board and CIA
}

\author{
Abstract \\ This case study discusses the Truman and Eisenhower administration's (1951-1953) short- \\ lived Psychological Strategy Board (PSB). Through the lens of declassified documents, the \\ article recounts the history and activities of the Board, including its relationship with the \\ Central Intelligence Agency (CIA) and clandestine projects that involve human \\ experimentation. Primary documents of the period suggest that institutional secrecy, \\ coupled with inconsistent information policies, largely shielded CIA's BLUEBIRD, \\ ARTICHOKE, and MKULTRA from the Board. This subject has not been previously reported \\ in the research literature, and supplements existing historical understanding of the PSB's \\ mission under the broad umbrella of psychological warfare.
}

\section{Keywords}

brainwashing, Central Intelligence Agency, Cold War, Eisenhower administration, human experimentation, Intelligence Advisory Committee, interrogation, national security, Nuremberg Code, Project ARTICHOKE, Project BLUEBIRD, Project MKULTRA, Psychological Strategy Board, psychological warfare, secrecy, Truman administration 


\title{
Murky Projects and Uneven Information Policies: A Case Study of the Psychological Strategy Board and CIA
}

Susan Maret

\begin{abstract}
This case study discusses the Truman and Eisenhower administration's (1951-1953) short-lived Psychological Strategy Board (PSB). Through the lens of declassified documents, the article recounts the history and activities of the Board, including its relationship with the Central Intelligence Agency (CIA) and clandestine projects that involve human experimentation. Primary documents of the period suggest that institutional secrecy, coupled with inconsistent information policies, largely shielded CIA's BLUEBIRD, ARTICHOKE, and MKULTRA from the Board. This subject has not been previously reported in the research literature, and supplements existing historical understanding of the PSB's mission under the broad umbrella of psychological warfare.

Keywords: brainwashing, Central Intelligence Agency, Cold War, Eisenhower administration, human experimentation, Intelligence Advisory Committee, interrogation, national security, Nuremberg Code, Project ARTICHOKE, Project BLUEBIRD, Project MKULTRA, Psychological Strategy Board, psychological warfare, secrecy, Truman administration
\end{abstract}

A definitive history of the Psychological Strategy Board (PSB) has yet to be written. But when it is eventually constructed, this history might situate the PSB as a major force in the institutionalization of information programs designed to shape beliefs and behavior. Through its almost invisible activities, the PSB, as a subcommittee under the aegis of the National Security Council (NSC), coordinated programs and operations with the Central Intelligence Agency (CIA), U.S. State Department, branches of the military, and other federal agencies involved in psychological warfare 
(Central Intelligence Agency 1951d, 1951g). ${ }^{1}$ "Psywar," as one declassified text of the period describes, is the "communication of messages, whether expressly or by implication" (Schramm, Katz, Kendall, and Vallance 1953,

11). On the other hand, "modern psychological warfare" is outlined as a tool for managing empire, not for settling conflicts in any fundamental sense. It has operated largely as a means to ensure that indigenous democratic initiatives in the Third World and Europe did not go "too far" from the standpoint of U.S. security agencies. Its primary utility has been its ability to suppress or distort unauthorized communication among subject peoples, including domestic U.S. dissenters who challenged the wisdom or morality of imperial policies. (Simpson 1994, $8)^{2}$

\section{Secrecy, Gaps in the Historical Record, and the PSB}

The PSB, as the behind-the-scenes coordinator of psychological warfare activities during the years 1951-1953, exemplifies the oft cited "secrecy is a form of government regulation" (Commission on Protecting and Reducing Government Secrecy 1997). Secrecy as a parallel form of government manifests through specific information policies, and in the case of the PSB, resulted in a dearth of public knowledge on its relationship with the NSC 10/5 Panel (Keane and Warner 2007, 257), Hoover's FBI, the National Military Establishment, ${ }^{3}$ the State-Army-Navy-Air Force Coordinating Committee (SANACC), the Joint Chiefs, and NATO (Department of Defense 1952b). Secrecy also cloaked knowledge of PSB's role in psychological warfare operations on a domestic scale. For example, the Board's relationship with social scientists in Cold War operations (Psychological 
Strategy Board 1952e; Price 2016), ${ }^{4}$ knowledge of the CIA's University Associates Program, established in 1951 (Cook 1983, 34), and CIA front organizations and publishing houses (Price 2016) are not widely known. ${ }^{5}$ The role of PSB's Panel D psychological programs in shaping the "most favorable psychological effects from the public reporting" of atomic, chemical, biological and nuclear weapons (Psychological Strategy Board 1952j, 1952a, 1952c; Terms of Reference 1952) is under-researched. PSB's actions, if any, when approached by CIA to exploit information on unidentified flying objects, which "appear to have implications for psychological warfare as well as for intelligence and operations" (Smith 1952a) are not known. Question abound regarding the PSB's role in early iterations of Operation Mockingbird ${ }^{6}$ and its relationship with the press (Parry-Giles 1996) and Rockefeller Foundation, the "founding fathers of communication research" (Gary 1999, 88). ${ }^{7}$

However, the subject of this article concerns another critical gap in the literature: the PSB's knowledge of the CIA's clandestine scientific research and development into behavior, addiction, drug interactions, interrogation techniques, sleep, and hypnosis carried out under the BLUEBIRD, ARTICHOKE, and MKULTRA programs. ${ }^{8}$ To better accommodate the wide range of primary materials related to the PSB, CIA, and clandestine projects, this article is divided into distinct sections that can be read as independent histories or in unison with other sections. First discussed in this case study is the role of NSC $10 / 5$ as a foundation for examining the PSB as a member of 
the invisible government, defined as "a loose, amorphous grouping of individuals and agencies drawn from many parts of the visible government" (Wise and Ross 1964, 3). The research literature is then reviewed concerning the PSB, CIA, and secret projects. Building on this background, I chart the creation of the Board, then report on inconsistent information policies that deeply influence, some sixty-five years after the fact, historical reconstruction of PSB's activities. Lastly, I focus on PSB's knowledge of, and participation with, three more well-known CIA clandestine projects, BLUEBIRD, ARTICHOKE, and MKULTRA. Through this investigation, I establish that information policies, including "island" secrecy led to the Board's fragmentary understanding of project budgets, planning, and operations. $^{9}$

\section{NSC 10/5, PSB, and the CIA}

The underlying basis for my exploration of the PSB are based in questions regarding the National Security Council's policy directive $10 / 5$. This directive authorized the PSB "to assure that its strategic concept for a national psychological program includes provision for covert operations" (National Security Council 1951; Lay 1951; Warner 1994; Central Intelligence Agency 1967). The once classified 10/5, titled Actions Taken by the National Security Council on the Scope and Pace of Covert Operations dated October 23, 1951, directed the PSB to participate in covert operations 
by

a. Determining the desirability and feasibility of programs and of individual major projects for covert operations formulated by or proposed to the Director of Central Intelligence.

b. Establishing the scope, pace, and timing of covert operations and the allocation of priorities among these operations.

c. Coordinating action to ensure the provision of adequate personnel, funds, and logistical and other support to the Director of Central Intelligence by the Departments of State and Defense for carrying out any approved program of covert operations. (National Security Council 1951)

Gen. Walter B. Smith noted in the Memorandum From Director of Central Intelligence Smith to the National Security Council that NSC 10/5 redefines the Central Intelligence Agency's responsibilities in a field which was probably not envisaged at the time the National Security Act of 1947, under which the Agency was established, was framed. This is the field of cold war covert activities, including guerrilla warfare. We have accepted these responsibilities as agents for the major Departments concerned and for projects which are approved by the Psychological Strategy Board. (Keane and Warner 2007, 252)

An additional memo, dated May 7, 1952 titled Briefing to the Psychological Strategy Board on Some 10/5 Problems, outlines the relationship between the PSB, State and Defense departments, and CIA's Office of Policy Coordination (OPC) on covert actions (Keane and Warner 2007, 257-265). ${ }^{10}$ Although NSC $10 / 5$ seemingly directs PSB involvement in CIA's covert programs, Barnes $(1982,656)$ describes the Board's oversight role as giving "nominal approval," and further fleshes out guidelines for such approval: 
There was thus considerable concern that clandestine operations were consistent with American policy abroad, but because any action capable of interpretation as bruising communist interests was thought to fit in this category, the freedom given for covert operations was considerable. ${ }^{11}$

Using 10/5 to explore the PSB and its knowledge of CIA's BLUEBIRD, ARTICHOKE, and MKULTRA is risky business, but it is not without foundation. The three CIA programs operated in secret to support clandestine and covert operations; furthermore, a read of NSC 10/5 does not differentiate between approval for support programs versus actual field (both covert and clandestine) operations. For example, MKULTRA is described as "the principal program for CIA development of chemical and biological agents which were to be 'capable of employment in clandestine operations to control human behavior'" (Senate Select Committee to Study Governmental Operations with Respect to Intelligence Activities 1976a, 389). On my part, these distinctions are a launching point to explore PSB's membership in the invisible government as well as any involvement in the BLUEBIRD, ARTICHOKE, and MKULTRA programs.

\section{A Review of the Literature: PSB and Genealogy}

The PSB, as a U.S. government based propaganda machine, reflects the dynamics of Cold War messaging in showing "how the practice of international relations was no longer the preserve of governments and foreign policy elites, but required the mobilization of entire populations" 
(Rawnsley 1999, 2). ${ }^{12}$ As the "nerve center for strategic psychological operations" (Psychological Strategy Board 1951j), the PSB is deeply connected to more contemporary projects that alter beliefs and opinions, and in essence, social reality. ${ }^{13}$ The PSB laid the institutional foundation for the development of initiatives to exploit, destabilize, and manipulate, as well as mold opinion, beliefs, and allegiances. For example, deception operations (Macdonald 2007), influence operations, ${ }^{14}$ information operations (Brown 2003), information warfare (Molander, Riddile, and Wilson 1996), military information support operations (formerly termed psychological operations), perception management /public diplomacy (Cull 2009; Lord 1998; Snow $2009,2010)$, strategic communication, and strategic influence are all the direct result of decades long social sciences research (Chomsky 1989; Daugherty and Janowitz 1958; De McLaurin, Rosenthal, and Skillings 1976) with their roots in the PSB as the interagency clearinghouse for psychological warfare (Memorandum For: Acting Assistant Director for Policy Coordination 1951; Briefings on Research in the Social Sciences 1952). ${ }^{15}$

As Scott Lucas $(1996,330)$ points out, "in the thousands of volumes on the United States and the Cold War, there is scarcely a mention of the PSB and the few passing references are dismissive." A research gap generally on the PSB substantiates Lucas' observation, but it is the Board's connection with CIA's BLUEBIRD, ARTICHOKE, and MKULTRA projects that is lost history. For example, the hearings of the Senate Committee on Labor and Public 
Secrecy and Society, Vol. 1, No. 2 [2018], Art. 6

Welfare, Subcommittee on Health held September 10, 12, and November 7, 1975, paved the way in disclosing information on the BLUEBIRD and ARTICHOKE projects. With the release of declassified documents the Commission obtained through FOIA, the country learned of once-secret budgets, contracts, experiments, and internal audits, such as CIA Inspector General J.S Earman's (1963) redacted Report of Inspection of MKULTRA (Marks 1979). There is no mention of the PSB in these particular hearings.

The subsequent 1975 Church Committee changed the trajectory of knowledge concerning BLUEBIRD, ARTICHOKE, and MKULTRA in terms of "a wide range of intelligence abuses by federal agencies, including the CIA, FBI, Internal Revenue Service, and National Security Agency" (United States Senate n.d.). While the Committee described the PSB as an "NSC subcommittee established in 1951 to determine the desirability of proposed covert action programs and major covert action projects" (Senate Select Committee to Study Governmental Operations with Respect to Intelligence Activities 1976a, 627), it did not differentiate between the Board and its successor, the Operations Coordinating Board (OCB). The Committee reported that "during the first two years of the Eisenhower administration, 1953-54, 66 projects were approved by the DCI in coordination with the Operations Coordination Board or the Psychological Strategy Board" (Senate Select Committee to Study Governmental Operations with Respect to Intelligence Activities 1976a, 56). Note here the PSB was abolished on 
September 2, 1953 with Eisenhower Executive Order 10483; we are left to ponder why the Church Committee did not differentiate between the short months of the PSB under Eisenhower and its successor, the OCB, regarding the sixty-six reported projects and specifically PSB's connection with BLUEBIRD, ARTICHOKE, and MKULTRA. These projects, discussed in Book 1 of the Church Committee hearings, are primarily associated with the CIA, and do not mention PSB's involvement. Here it is critical to interject that researchers and the media have not had complete access to Church Committee records as a select group remain classified. ${ }^{16}$

A final hearing, the 1977 Senate Select Committee on Intelligence, altogether neglected the PSB and its possible participation in the BLUEBIRD, ARTICHOKE, and MKULTRA programs. The hearings are nonetheless notable for the remarks of then CIA Director Adm. Stansfield Turner, who observed that his testimony does "not tell the story; they tell pieces of it" (Senate Committee on Human Resources 1977, 128).

Although journalists and scholars have made remarkable strides in unmasking the utter complexity of the BLUEBIRD, ARTICHOKE, and MKULTRA programs (Scheflin and Opton 1978; Marks 1979; Thomas 1989, Hunt 1991; Cannon 1992; Ross 2006; Brown 2007; McCoy 2007; Streatfeild 2007; Albarelli 2009, 2013; Moreno 2012; Jacobsen 2014; Krishnan 2017), few associations are made to PSB's knowledge of the three programs. In turn, those works that do examine the PSB often do not link the Board to the 
Secrecy and Society, Vol. 1, No. 2 [2018], Art. 6

clandestine projects we are concerned with in this article (Paddock 1982; Warner 1994, 2014; Lucas 1996; Hixson 1997). Christopher Simpson's (1994) seminal Science of Coercion: Communication Research and Psychological Warfare, $1945-1960$ outlines the evolution of U.S. psychological warfare during the years 1945-1960, but offers limited insight into the relationship between PSB and CIA. Simpson attributes his brief mention of the PSB to issues with security classification and scattering of records across archives. Since the publication of Science in 1994, these factors have lessened due to declassification initiatives and availability of digital collections. Simpson's $(1994,4)$ framing of psychological warfare as a "communication device" however, is especially relevant to the PSB's programs in terms of the "relationship between the production of 'knowledge' - in this case preconceptions about communication and coercion - and the social and political conditions of a particular era."

This article therefore is a step towards bringing the hidden history of the PSB to the surface. To accomplish this task, and in institutional ethnography fashion, I borrow from Dorothy Smith $(1990,62)$ the "realities to which action and decision are oriented are virtual realities vested in texts." The primary materials documenting PSB operations during the years 19511953 offer a chronology of events, are a diary of information control, and reveal political tensions between PSB staff and member agencies exposing the energetics of power/knowledge. In examining these texts, however, we 
must address Georg Simmel $(1950,352)$ on the publicity-bearing influence of writing, especially the notion that writing is "opposed to all secrecy" and "possesses an objective existence which renounces all guarantees of remaining secret." Simmel, who gave us profound insights into secrecy across the social landscape, did not distinguish between degrees of concealment in institutions; his friend and colleague Max Weber filled in the blanks on the territorialization of information/knowledge within bureaucratic institutions. We must confront Simmel's assumption, keeping in mind that neither the act of "writing" nor its dissemination in the form of texts (e.g., memorandum, document destruction schedules) equates to total publicity or transparency. Redaction, or the blacking out of information deemed sensitive, is one such example where Simmel falls flat. Redaction is nothing less than a side effect of the national security state, obscuring individuals, conversations, dates, relationships, and policies. These elements are critical to evidence building and central to accountability. Many, if not most, materials cited in this article contain some level of redaction. Redaction conceals writing.

Through primary materials preserved at the Truman and Eisenhower presidential libraries, declassified in the CIA's CREST database, which includes documents from presidential libraries under the RAC program, ${ }^{17}$ the MKULTRA Collection at Black Vault, National Security Archive's Briefing Books, the subscription database U.S. Declassified Documents (formerly the 
Declassified Documents Reference System), and documents I received through FOIA, it is possible to partially (re)construct the PSB's knowledge and involvement in the once-black BLUEBIRD, ARTICHOKE, and MKULTRA projects. Primary materials allow us to place the PSB more concretely under the lens to scrutinize its ethics, inner politics, bureaucratic relationships, and ideological differences (Wolfe 2000); the documents cited in this article are also a vehicle in which to peer into the national security complex, which gave wide berth to the meaning and application of psychological warfare.

I theorize here that broad definitions of psychological warfare gave license to studies that included "brain warfare," sensory deprivation, interrogation, the study of specific drugs on behavior, and the active search for a "truth serum" (Senate Select Committee on Intelligence 1977, 25-33). That is, I speculate that psychological warfare was extended out from the realm of propaganda and modification of public opinion to the active research and development of numerous chemicals and drugs (Drugs n.d.; MKULTRA Briefing Book n.d.), technologies (e.g, ECT, polygraph), and interventions (e.g., isolation, sleep deprivation) in order to unlock methods to alter agency, behavior, consciousness, and in some cases, break minds and spirits. The specter of these programs exists today in the use of techniques that concern the manipulation of information to "create consent" (Lippmann 1929 [1922], 248) and invent "positive misinformation" (Friedrich 1972, 177), as well as in the development of certain neurotechnologies (e.g., fMRI, 
transcranial magnetic stimulation) and "neuropharmacological interventions" (Dubljević and Racine 2017). The R\&D conducted under the BLUEBIRD, ARTICHOKE, and MKULTRA programs institutionally set the stage for "enhanced interrogation" techniques (McCoy 2007; Brown 2007; Price, 2007a, 2007b, 2016), ${ }^{18}$ perhaps even "neurowarfare" (Krishnan 2017), as requisites for protecting and strengthening national security, indeed what is characterized as "neurosecurity" (Moreno 2012).

In this way, PSB's knowledge of CIA black programs with the cryptonyms BLUEBIRD, ARTICHOKE, and MKULTRA is critical U.S. social history, and therefore of genealogical concern. As I see it, genealogy as it relates to the PSB, the CIA, and clandestine projects, concerns a "vision of critique as an inquiry into those historical conditions of possibility that constrain us not with the iron fist of necessity, but with the gentle yet persuasive arm of contingency" (Koopman 2013, 19). To unlock the genealogical footprints that involve the rot of secrecy and national security is to peel away the edges of authority, democratic right to know, and ethics. More often than not, the double-edged sword of national security is used as justification for initiating, conducting, and funding secret R\&D programs, with this same claim applied as a basis for concealing details from friends and foes alike. The testimony of Dr. Sidney Gottlieb to the Senate Subcommittee on Health and Scientific Research captures this dual edged nature of national security secrecy. Gottlieb, former Director of the CIA's Technical Services 
Secrecy and Society, Vol. 1, No. 2 [2018], Art. 6

Staff's (TSS) Chemical Division, which conducted R\&D into hallucinogens, poisonous plants, and biological and chemical agents, reflected on these aspects of secrecy. Gottlieb notes that harnessing the academic and research community of the United States was an effort to provide badly needed answers to some pressing national security problems, in the shortest possible time, without alerting potential enemies to the U.S. Government's interest in these matters. (Senate Committee on Human Resources 1977, 172)

\section{A Moment in Time: The PSB and Institutionalization of Psywar}

Following the document trail, a proposal for National Psychological Board (NPSB) was initiated by the U.S. State Department January 14, 1950 (U.S. Department of State 1950; Barrett 1950; Lilly 1951). The board, as the State Department inventoried the body, authorized the Secretary of State for "coordinating informational and psychological strategy to meet situations wherever joint action by more than one agency of the Government is required in this field" (U.S. Department of State 1950). NSC 74, A Plan for National Psychological Warfare, written by Under Secretary of State James Webb in July 1950, "recommended that a national psychological warfare organization be established. Pursuant to this recommendation and to NSC $59 / 1$, the Department of State announced on August 17 the creation of a National Psychological Strategy Board under the Secretary of State" (Keane and Warner 2007, 20, 99). NSC 74 "never received the formal approval of the Council, but was used for reference in subsequent studies of this subject" (Keane and Warner 2007, 21). Planning discussions for the new board 
continued throughout 1950 (Keane and Warner 2007). By January 18, 1951, the Draft Directive on the National Psychological Effort outlined the board's composition, which included assigning it under the purview of the NSC (Keane and Warner 2007, 87-88). In February, 1951, a subject paper, which originated in the Executive Office of the President, echoed this organizational placement of the PSB, where the "mission of the Board under the terms of the paper would be solely related to national strategy and policy in the field of psychological warfare (propaganda)" (Johnston 1951). ${ }^{19}$ This policy paper also raised the matter of CIA providing "intelligence support" to the new NPSB/PSB (Central Intelligence Agency 1951a; Central Intelligence Agency 1951b). Out of these and other discussions, the Psychological Strategy Board was born. The Presidential Secret Directive of 1 April 1951 Establishing a Psychological Strategy Board gave bureaucratic life to the PSB (Psychological Strategy Board 1951b). An April 4, 1951 date is also given as the Board's establishment (Psychological Strategy Board 1951e) with the White House publishing an "abbreviated" version of the Directive on June 20, 1951 (Truman 1951; Keane and Warner 2007, 120).

Between the months of April and June, the matter of PSB's organization was the subject of back and forth discussion between agencies. A planning memo, Implementation of the Presidential Directive of April 4, 1951 (n.d.), outlined the "recruitment of a really competent staff"; anticipating the October 23, 1951 NSC 10/5, "policy guidance for covert 
Secrecy and Society, Vol. 1, No. 2 [2018], Art. 6

operations is of concern to more than one department, this guidance be coordinated and issued to the CIA by the new Psychological Board" (Wisner 1951). However, in May 1951, the PSB was darkly characterized by DCI General Walter B. Smith as "something that should be entirely independent of an altruistic agency" (Central Intelligence Agency 1951f). DCI Smith further conceptualized the PSB as a body that would provide policy guidance for CIA on covert actions. As the Church Committee notes in its hearings, Smith called for NSC restatement or redetermination of the several responsibilities and authorities involved in U.S. covert operations. More importantly, Smith proposed that the newly created Psychological Strategy Board provide CIA guidance on the conduct of covert operations. The NSC adopted Smith's proposal making the Psychological Strategy Board the approval body for covert action. The body that had been responsible for exercising guidance over the CIA had received it from the DCI. (Senate Select Committee to Study Governmental Operations with Respect to Intelligence Activities 1976b, 35)

In part, the PSB was perceived as a "general staff for the direction of the cold war" (Little 1954, 39) with Presidential Directive 128 serving as the North Star for the coordination of psychological operations (Truman 1951). Per the Directive, the Board reported to the National Security Council, staffed by members such as "the Undersecretary of State, the Deputy Secretary of Defense, and the Director of Central Intelligence, or, in their absence, their appropriate designees" and "an appropriate representative of the head of each such other department or agency of the Government as may, from time to time, be determined by the Board" (Truman 1951). Membership in the PSB was based on the perception that 
its members would be men who enjoyed such prestige that the operating agencies would consider guidance approved by the Board as being mandatory. This was justified on the basis that the major psychological operations are conducted by either the Department of State, the Department of Defense, or the CIA, the undersecretaries of which (or the director in the case of CIA), constitute the membership of the Board. (Little 1954, 21)

Early in its formation, concern was voiced "that the scope of the Board's responsibility is very broad and covers every kind of activity in support of U.S. policies except overt shooting and overt economic warfare" (Psychological Strategy Board 1951b). The CIA too pondered its relationship with the PSB. The Agency found the PSB "represents potentially one of the most effective elements of the Government to assist CIA in the prosecution of the activities held responsible in NSC 10/2," but argued the Board's activities should be "broad enough to encompass the group of Governmental activities having psychological impact" (Central Intelligence Agency 1951d). ${ }^{20}$ More to the point, the PSB

must be permitted to come to grips with the operational and planning problems of the agencies whose activities it is coordinating to a far greater extent than has previously been accomplished at this level in the government. (Central Intelligence Agency 1951d)

In this same memo, CIA recognized "the extreme value of PSB to CIA interests," although it had "security and propriety" concerns for the Agency (Central Intelligence Agency 1951d). The CIA proposed a set of security/secrecy measures for the PSB that ranged from recycling personnel through special matter panels to limiting information to "absolutely necessary and need to know" (Central Intelligence Agency 1951c). ${ }^{21}$ 


\section{The PSB in Action}

At an August 13, 1951 meeting, the PSB's organizational structure was finalized to include the creation of three offices: Office of Plans and Policy, Office of Coordination, and Office of Evaluation and Review (Psychological Strategy Board, 1951h, 1951i; Johnson 1951). In order to "execute its role," the Psychological Strategy Board (1951f) stated that it would "formulate and promulgate overall policies, programs, and objectives for psychological operations; including overall strategic plans in such detail as to enable operational planning by departments and agencies." By September, the proposed number of PSB staff consisted of 42 officers and 57 supporting administrative and clerical positions (Psychological Strategy Board 1951e). Gordon Gray was the Board's first director. ${ }^{22}$ In June 1951, The New York Times described the PSB as central in formulating "strategy against Russian communism in all but military operations" (Waggoner 1951). And as previously mentioned, the October 1951, NSC 10/5 institutionalized PSB's position in relation to CIA-run operations.

In response to the establishment of the PSB and psychological operations as specified in NSC Memorandums $10 / 2,10 / 5$, and 59/1, the Department of Defense (DoD) published the 1952 DoD Directive C-5132.1, titled Organization, Office of Psychological Policy (Gough 2003, 11). This directive established the Office of Psychological Policy, led by Deputy for Psychological Policy, 
formally known in Defense parlance as the Deputy Assistant to the Assistant Secretary of Defense for International Affairs - Psychological Policy. DoD signaled the importance it gave this new office by specifying in the directive that the Deputy for Psychological Policy 'shall have direct access to the DoD member of the PSB on matters pertaining to PSB and to the Assistant Secretary of Defense for International Security Affairs on other matters.' (Gough 2003, 11)

PSB funding originated through equal contributions of $\$ 188,000.00$ from CIA and the Defense and State Departments (Houston 1952), with projected staff for 79 permanent positions for fiscal years 1952 and 1953 (Gray 1951; Psychological Strategy Board 1951d). ${ }^{23}$ The January 1952 Memorandum for Record: Legislative Problems of the Psychological Strategy Board includes CIA concern that its secret "activities in the psychological warfare field may be dragged into that Subcommittee." With some candor as to budgetary entanglements and political alliances, the Agency observed:

We have just succeeded in getting CIA clear of such subcommittees with the assistance of the Bureau of the Budget and our committee friends. From our point of view it would have been preferable to lump the PSB administrative budget openly as a part of the budget of the National Security Council, of which PSB might be considered an adjunct. This device would have had the advantage of bringing all of the PSB funds under the purview of the Armed Services Appropriations Subcommittee, and Chairman Mahon and Senator O'Mahoney could then have controlled the situation to a greater degree. (Houston 1952)

In March 1952, CIA responded to PSB Director Gordon Gray's recommendation to make the Board's Report to the President public. In spite of any potential capital that might be gained from release of the Report, CIA was reticent to have its contents disseminated as it may be 
too revealing of sensitive information and relationships which in some particulars are invidious and provocative - more apt to stir up discord than to produce harmony - and, therefore, to be deleted...the report infers a number of inter-agency differences and disputes that would not improve with public airing. Moreover, portions of the report would invite undeserved and unwarranted criticism of the Government criticism for having done a great deal less than is actually the case in the realization of the need for and the development of machinery to carry out psychological warfare measures. (Central Intelligence Agency 1952d)

Additional materials from this time period also indicate concern over the physical control and custody of information. For example, Tracy Barnes, who at different times assumed the role of PSB Deputy Director and Acting Director, reported that he kept sensitive documents locked in his office safe (Psychological Strategy Board 1952g). Other correspondence between PSB and CIA illustrate tight control over documents (Psychological Strategy Board 1951a, 1953a), with one CIA memo informing PSB that "reports of the various members shall be made available to the others except on matters affecting the security of CIA operations. The CIA member may make his report available only to the Chairman and, in the field, to the - [redacted]" (Psychological Strategy Board 1952a). A June 9th memo from Allen Dulles (1952) to CIA Deputy and Assistant Directors further records ongoing segregation and control of information.

Although the PSB fell under the aegis of the NSC, it did not have a representative on the Council. Gordon Gray recommended the director of PSB hold a seat on the NSC, but it was not deemed "desirable" (Smith 
1952b). This led to "disputes" between the CIA and PSB, and "denied the representation he deemed vital to achieving a coordinated psychological offensive, Gray resigned in May 1952 as PSB director after less than a year on the job" (Hixson 1997, 190).

\section{Beginning of the End}

In the June 21, 1952 Memorandum for the Chairman, Psychological Strategy Board, President Truman (1952) wrote that he was giving "consideration" to amending the April 4, 1951 Directive that established the PSB. By June 30, the President's Committee on International Information Activities $(1952,60)$ opined that the "national information program has suffered from the lack of effective central direction...in spite of the establishment of the Psychological Strategy Board... and various agencies have largely gone their separate ways." The President's Committee, or Jackson Committee after chairman Deputy Director of the CIA William H. Jackson, found "the present conception of the Psychological Strategy Board...unsound," and critically observed the PSB was "charged with planning, coordination, and evaluation of 'psychological operations,' a term which is nowhere adequately defined." The Jackson Committee acknowledged "so much controversy between PSB and the established planning agencies within the State Department" that it recommended the Board be "abolished" (President's Commission 1952, 89-90). ${ }^{24}$ It is 
Secrecy and Society, Vol. 1, No. 2 [2018], Art. 6

interesting to note that Gordon Gray was a member of the President's

Committee and a contributor to the report (President's Commission 1952; Gray 1973).

In the strongly worded - and contemporary - August 1, 1952 Status Report on the National Psychological Effort and First Progress Report, the PSB turned the tables on the concept of psychological. With its sharp analysis, we are left to question the behind-the-scenes events that led to the Board's commentary. I leave this investigation to future researchers, but find the following passage from the PSB's Status Report astounding in its critical assessment of U.S. foreign policy:

Certain national policies of the United States are psychologically damaging in various areas of the non-Soviet world. In the Moslem world this is true of United States policy toward Israel; in areas under European domination it is true of United States acceptance of the colonial policies of its NATO allies; in Britain and elsewhere it is true of United States policy toward China. The same may be said of certain primarily domestic matters. For instance, efforts to counteract communist exploitation of the race relations problem in the United States have not been fully successful. Likewise, the restrictive immigration policy of the United States, most recently embodied in the McCarran Act, has damaging psychological repercussions abroad. (Psychological Strategy Board 1952f)

In early 1953, it appeared business as usual for the PSB and its interagency coordination of psychological warfare activities. The January Handbook on Psychological Strategy Functions and Procedures describes the PSB as responsible for "psychological strategic planning," with the State Department supplying Board staff "appropriate intelligence research materials and various types of policy information as requested" (McWilliams 
1953). Newly elected Dwight D. Eisenhower (1953; Central Intelligence Agency 1953a) wrote to Acting Director George A. Morgan on March 5, 1953 requesting that Special Assistant to the President C.D. Jackson be granted membership to the PSB. ${ }^{25}$ On March 19, James Reston (1953) of The New York Times announced that Jackson had assumed leadership of the Board. ${ }^{26}$

By September 2, 1953, Reorganization Plan No. 8, 1953 (67 Stat. 642) established the United States Information Agency, which the Church Committee notes assumed the functions of the PSB. According to the Committee, the Eisenhower administration found "a need for improving the manner in which NSC policies were carried out" and so created the Operations Coordinating Board (Senate Select Committee to Study Governmental Operations with Respect to Intelligence Activities, 1976c, 251). With Executive Order 10483 Establishing the Operations Coordinating Board (September 2, 1953), the final blow felled PSB as a psychological warfare coordinating body, with its projects transferred to the Operations Coordinating Board.

\section{PSB's Legacy}

PSB's international information activities included manipulation of public opinion and the press within foreign countries (Simpson 1994), as well as staff testing psychological warfare methods overseas in order to influence foreign politics (Wisner 1952). PSB programs included psychological 
Secrecy and Society, Vol. 1, No. 2 [2018], Art. 6

operations during the Korean cease-fire (Psychological Strategy Board $1951 k) ;$ PSB was also involved in psychological programs planned to lead to the "reduction of Communist power in Italy" (Psychological Strategy Board 1952i) and France (Psychological Strategy Board1953e). A staff study on psychological operations in Southeast Asia (Psychological Strategy Board 1952d), "a plan for coordinated psychological operations" in Thailand (Psychological Strategy Board 1953d), and psychological operation plans in the Middle East (Psychological Strategy Board 1952b, 1952d) were also part of the Board's global outreach. Defeating the former Soviet Union through "doctrinal (ideological)" warfare (Psychological Strategy Board 1952e) was the paramount strategic goal. Psychological warfare efforts focused on such methods such as exploiting information on refugees from the Iron Curtain (Action 1951) and the "Soviet orbit" (Psychological Strategy Board 1951g, 1952d), as well as conducting "preparatory work" in anticipation of Stalin's death (Psychological Strategy Board 1952f; Lucas 1996). The PSB left its mark on U.S. psychological warfare policies through conferences on psychologically-oriented "evaluation techniques and criteria (e.g., with the Evaluation Branch of OGPW, with CIA, and at the Fort Bragg Psywar Center" (Psychological Strategy Board 1953d) and advising agencies on "psychiatric warfare." ${ }^{27}$

In the wake of its termination and the creation of the OCB, the PSB was described as being "premised on the fallacious concept of an 
independently-existing psychological strategy" (Cutler 1956, 448). Walter L. Hixson $(1997,190)$ goes further to observe the Board "failed to achieve its goal of uniting the executive branch, State, Defense, all branches of the military, CIA, Congress, the Bureau of Budget, academic specialists, and corporate interests behind a campaign of psychological warfare." In an interview reflecting on his time on the PSB, Gordon Gray (1973) linked OCB's administrative roots with the Board, observing "the PSB had been the necessary, although wobbly, precursor to the OCB. I think we couldn't have had an effective OCB without the experiences of the PSB, but that may be rationalization."

\section{Murky Projects + Information Policies $=$ History in Pieces}

In this portion of my discussion, I identify significant problems that hinder the ability to document historical connections between the PSB, CIA, and the BLUEBIRD, ARTICHOKE, and MKULTRA programs. These problems, or institutional barriers, constrain research and thus have a bearing on the ability to fully document PSB and CIA relations. These barriers range from declassification/redaction and continuing classification, to limited copy policies and compartmentalization, the latter an interconnected practice where secrecy is not only concealment, but containment and segmenting of information and communications. As Lewis Mumford observes (1970, 264), "the key to exercising arbitrary power is to restrain the communication of 
Secrecy and Society, Vol. 1, No. 2 [2018], Art. 6

individuals and groups by subdividing information." Additional institutional barriers include deliberate destruction of documents, lack of uniform indexing, and unevenly followed preservation policies.

First, there is no doubt that declassification, or the downgrading and public release of formerly classified materials, is a significant tool in revealing the underlying forces behind government policies and events. ${ }^{28}$ Under this regime, however, information is doled out in bits and bytes over the course of decades, as in the case of the JFK assassination files. ${ }^{29}$ The declassification process often creates a screen between partial and full knowing. In the case of the PSB, seventy percent of documents are partially declassified and have only minimal redaction; 9,200 pages of materials remain classified in whole or in part at presidential libraries, documents otherwise open for research in the Truman and Eisenhower presidential libraries. ${ }^{30}$ The status of still classified or partially declassified PSB documents held by CIA is currently unknown.

Lack of official records is another barrier to research. In its second meeting (August 13, 1951), the PSB agreed that it would "meet only when there are important problems to discuss" (Psychological Strategy Board 1951f). From July 2, 1951 through January 15, 1953, only seventeen sets of declassified, redacted minutes are available for examination. Limited availability of official minutes makes internal correspondence between PSB staff and agency members even more significant in capturing the history of 
the Board's interagency relationships and policymaking.

Limited copy policies are another institutional barrier. These policies are tied to compartmentalization as an official secrecy mechanism. As it relates to the PSB, a limited copy policy is documented in a memo titled Psychological Strategy Board: Top Secret Documents, which describes types of Psychological Strategy Board (n.d.) publications often issued in the single digits. CIA memos of the same time period were also subject to a limited copy policy. CIA Inspector General J.S. (John) Earman's account of the MKULTRA program substantiates a limited copy policy. Earman reports "minimum documentation in keeping with the high sensitivity of some of the projects," and following the limited copy policy, restricted his report "of the MKULTRA program in one copy only, in view of its unusual sensitivity" (Earman 1963, 1). A variation of the limited copy policy is not producing any documentation (Earman 1963, 8). Working in tandem with limited copy policies, compartmentalization restricts knowledge to privileged parties. For example, IG Earman describes "just two individuals in TSD who have full substantive knowledge of the [sic, MKULTRA] program and most of that knowledge is unrecorded" (Earman 1963, 5-6).

Deliberate destruction of documents through official and informal policies is still another institutional barrier to research and historical reconstruction. A document titled List of PSB Documents Destroyed, dated September 22, 1952, not only inventories specific titles of documents 
destroyed but the number of copies. For example, the "working draft" of copies 16-18 of the Psychological Strategy Plan Prescribing Specific Courses of Action with Respect to Soviet Harassment of Berlin is reported destroyed along with eight additional copies. In essence, these details are a metric that is useful to information professionals and researchers concerned with preservation and the writing of history.

During the Church Committee hearings, the existence of CIA's rule CSI 70-10 "retirement of inactive records" regulation was revealed. As reported in the hearings, the regulation is characterized as an official agency preservation policy,

not a matter of convenience or of storage but of conscious judgment in the application of the rules modified by knowledge of individual component needs. The heart of this judgment is to ensure that the complete story can be reconstructed in later years and by people who may be unfamiliar with the events. (Senate Select Committee to Study Governmental Operations with Respect to Intelligence Activities 1976a, 404)

But as the Church Committee learned, "retirement" was not a uniformly followed by CIA; document destruction was instigated by individuals associated with compartmented projects. During the Senate Committee on Labor and Public Welfare, Subcommittee on Health hearings, then CIA Deputy Director Carl E. Druckett revealed that destruction of MKULTRA records was informally approved by DCI Richard Helms:

Mr. Druckett: I can only tell you that the information that we have, in fact, uncovered suggests that documents were destroyed by the individuals who were directly involved in the program on instruction from Dr. Gottlieb. 
Senator Kennedy: And you do not know who gave him the instruction?

Mr. Druckett: The indications are in the handwritten note of one of the individuals who was involved, that he was told by Dr. Gottlieb - he did not personally hear this - that Mr. Helms, the [sic, CIA] Director at the time, gave him the instruction. (Senate Committee on Labor and Public Welfare, Subcommittee on Health 1975, 280 $)^{31}$

It is interesting to note the Advisory Committee on Human Experimentation $(1995,646)$ reports (emphasis added) that records were "substantially destroyed at the direction of then-Director of Central Intelligence Richard Helms in 1973." The wholesale destruction of these records by secret "island" parties within CIA indicates that information policies were not universally followed for documents considered embarrassing and/or potentially criminal; furthermore, select individuals close to classified projects decided the fate of records. The destruction of project records, as the Church Committee identified, "made it impossible" to identify, locate, and provide followup care to unwitting individuals of CIA experimentation. Furthermore, as the Committee observed, records destruction

made it impossible for the Select Committee to determine the full range and extent of the largest CIA research program involving chemical and biological agents...finally, it prevented the Committee from determining the full extent of the operations which made use of materials developed in the MKULTRA program. (Senate Select Committee to Study Governmental Operations with Respect to Intelligence Activities 1976a, 404) ${ }^{32}$

The destruction of those inventories documenting destruction of records is yet another barrier. During its investigation, the Advisory 
Committee on Human Experimentation $(1995,795)$ found that "records documenting the destruction of records had been lost or destroyed."

Destruction schedules are crucial discovery tools used by researchers to confirm identities, dates, and interagency communication, the necessary ingredients of any federal agency history. Although redacted, the Memorandum for the OSD Classified Mail and Records: Subject Destruction of Classified Material, dated October 30,1951, called for the destruction of a document on Project ARTICHOKE and requested a "Certificate of Destruction furnished to the CIA" (Central Intelligence Agency 1951c). ${ }^{33}$ This document reveals important details such as number of copies ( 2 of 5 ), dates (May 15, 1952), and agencies with access (Secretary of Defense, including Army and Navy, and CIA's TSS, or Technical Services Staff). A suite of records attached to the Memorandum indicate that the "Staff Study on Special Interrogations (Project ARTICHOKE)" was scheduled for destruction; also attached is a BLUEBIRD document, an archival rarity that indicates the concurrency of the BLUEBIRD and ARTICHOKE projects. This latter memo reveals additional details of significance, such as the U.S. Army, Fort Belvoir having access to TSS information and the use of the "Third Agency employee," bureaucracy speak for the Third Agency Rule. The Rule, used here in 1952, prohibits one agency from sharing and/or disseminating materials originating from another agency (the third agency) without the consent of the originating agency. This detail is central to establishing agencies with security access and those "who 
knew what and when" questions.

Still another barrier to research is the problem of records segregated from an agency's main indexing system. In August 1977, eighteen boxes labeled Project ARTICHOKE were located by CIA that were not part of the Office of Security (OSI) file index. After review, CIA determined that only fourteen boxes actually contained materials on ARTICHOKE. Among the items discovered were a "one ampule of Thorazine...a display board containing sample samples of several drugs - some of which then being studied (redaction). The boxes also held a "crudely fashioned automatic injection device" tested by CIA (Central Intelligence Agency 1977b). Director of Security Robert W. Gambino wrote that "it was presumed that the material had not previously been reviewed during the Congressional inquiries into Agency drug-related activities" (Central Intelligence Agency 1977b). One reason for this lack of review may stem from CIA's then archival practices, where files called "convenience or working files" were not "readily retrievable because they are not official records and they are not indexed as such" (as cited in Theoharis 1984, 68). Along these lines, Dr. Robert Lashbrook raised the issue of "control files" in his testimony before the Subcommittee on Scientific Research of the Committee on Human Resources. ${ }^{34}$ A troubling exchange between Lashbrook and Senators Edward Kennedy and Richard Schweiker revealed CIA's use of a technique termed "boilerplate" or "cover file," which Lashbrook describes as a type of records camouflage invoked for 
secrecy-security purposes. Lashbrook informed the Committee that "what was actually signed off on was not the same as the actual proposal, or actual detailed project" (Senate Committee on Human Resources 1977, 111). In other words, cover files or boilerplates were "not revealing of their substance" (Senate Committee on Human Resources 1977, 111).

As outlined here, these institutional information barriers add up to a less than ideal means to (re)construct the history of an agency's secret programs and operations. Moreover, the particular barriers discussed here are catastrophic in terms of their influence on trust in an agency's competence to conduct public business, even if that business is conducted in secret. In some cases, these barriers also present a challenge for those federal officials, who decades after the fact, are left as apologists for actions in which they did not participate or have knowledge of, yet remain responsible for interpretation of policies and the historical record. ${ }^{35}$ This finer point is illustrated in the dialogue between Dr. Sayre Stevens, Carl E. Duckett of CIA, and Sen. Edward Kennedy during the hearings of the Senate Committee on Labor and Public Welfare, Subcommittee on Health (1976, 272-3):

Dr. Stevens: In an effort to simulate conditions, the Agency worked through the Bureau of Narcotics from perhaps 1953-1963 to test the effects of certain drugs including LSD, on unwitting subjects in social situations. The details of this testing are not in our records, but it appears that individuals were administered drugs, without their knowledge in normal social situations, to study their behavior. No follow-up or monitoring was normally possible. This program began in 1954 or perhaps 1953 at one location and was expanded to another 
location in 1961.

Senator Kennedy: Is this 1953? My copy says 1955.

Dr. Stevens: I think in checking the records again we have an indication that something was going on by February 1954 so it could have been 1953.

Mr. Duckett: That was a change we made this morning, and it was made because we found indications we had not previously see on this subject.

Senator Kennedy: What records are these?

Mr. Duckett: I have a document dated 10 February 1954, and it is that document that suggests certainly something was going on at the time, and therefore, we can presume it may very well have started as early as 1953.

With these interconnected barriers in mind, below I report my findings on PSB's relationship with CIA's BLUEBIRD, ARTICHOKE, and MKULTRA programs.

\section{PSB and the Projects: BLUEBIRD, ARTICHOKE, and MKULTRA}

Without acknowledging projects, in 1975 CIA recounted its turbulent history of Cold War experimentation. In its remarks - that illustrate the double-edged nature of national security secrecy - CIA divulged that thirty universities and research centers participated in its projects:

By 1953 , this activity led to the establishment of a fairly large and complex external research program which ranged from basic research on Lysergic Acid and other compounds to extensive testing and experimentation. More than thirty different universities and institutions were involved in this program. Basic work included chemical studies, tissue studies, and toxicological investigations. Testing on animals and 
human volunteers then followed. There was by this time a growing body of technical literature on the effects of LSD on humans. As the program developed, new materials and techniques for influencing behavior were also investigated. A significant feature of this effort was the use of covert funding techniques to protect the nature of our foreign intelligence concerns. (Central Intelligence Agency 1975b, 5)

Through FOIA requests most likely submitted by John Marks, just two years later, new records on clandestine projects were discovered by CIA. The Senate Select Committee on Intelligence $(1977,3)$ describes the records as detailing "a far more extensive series of experiments than had previously been thought. Eighty-six universities or institutions were involved." At the Senate Select Committee hearings, CIA Director Stansfield Turner inventoried the institutions to approximately 44 colleges and universities, 15 research, facilities or private companies, 12 hospitals/clinics, and 3 penal institutions, including the Pennsylvania based Holmesburg Prison (Marks 1979, 160; Senate Select Committee on Intelligence 1977). ${ }^{36}$ The CIA, according to the Senate Select Committee on Intelligence $(1977,3)$ "...used university facilities and personnel without their knowledge. It funded leading researchers, often without their knowledge."

Outlined below are brief accounts of the BLUEBIRD, ARTICHOKE, and MKULTRA programs, with special emphasis placed on PSB's knowledge. The three projects should not necessarily be thought of as chronological as often reported in the popular and scholarly literature. Instead, I ask readers to visualize a simple Venn Diagram where projects overlapped and intersected 
for moments in time, often reflecting evolving political agendas, shifting policies, and in some cases, comparable research and development projects between agencies, researchers, and institutions.

\section{Project BLUEBIRD (1949-53)}

The precise inception date for the BLUEBIRD program is lost to the ravages of documents destruction, but one report dates the project began as early as 1949 (Chamberlain 1975) and continuing to at least November 1953 (Central Intelligence Agency 1953a). Surviving BLUEBIRD documents exist by way of John Marks (1979) who received them under FOIA. These declassified documents are present in digital format in CIA's CREST, the U.S. Declassified Documents database, and Black Vault's MKULTRA Collection. ${ }^{37}$

It is theorized the BLUEBIRD program grew out of human experimentation by Nazi physicians and scientists (Marks 1979; Advisory Committee on Human Radiation Experiments 1995b; Price 2016; also see Pross 1991) who were captured or surrendered to the Office of Strategic Services and U.S. forces at the end of WWII under Operation or Project Paperclip (Hunt 1991; Jacobsen 2014; Loftus 2010). Sidney Gottlieb frames Project BLUEBIRD in an alternate way, stating that "as I remember it, was also an Office of Security concept, possibly never realized, which later evolved into a TSD-sponsored activity looking into brainwashing, and ultimately included the Society for the Investigation of Human Ecology" (Senate Committee on Human Resources 1977, 170). 
Secrecy and Society, Vol. 1, No. 2 [2018], Art. 6

However, surviving documents reveal that BLUEBIRD was clearly more than a "concept." BLUEBIRD "established a behavioral control program within the CIA in close collaboration with the Office of Scientific Intelligence, but also made use of the BLUEBIRD's research results through the interrogation teams operating across the CIA" (Marks 1979, 23). That is, Project BLUEBIRD provided for the "immediate establishment of interrogation teams for the operational support of OSO [Office of Special Operations] and OPC activities" (Director of Central Intelligence 1950). BLUEBIRD had a strategic national security focus in

(a) discovering means of conditioning personnel to prevent unauthorized extraction of information from them by known means,

(b) investigating the possibility of control of an individual by application of special interrogation techniques,

(c) memory enhancement, and

(d) establishing defensive means for preventing hostile control of Agency personnel. (Senate Select Committee on Intelligence 1977, 67)

At the end of 1950, former OSI officer Morse Allen became head of the BLUEBIRD program (Jacobsen 2014, 318). In a undated memo titled Project BLUEBIRD, Col. Sheffield Edwards (n.d.) called for a meeting on March 14 (1951?) to discuss "operational requirements for highly specialized interrogation teams." In this memorandum, Edwards (n.d.) states that BLUEBIRD "is regarded as of the highest security classification and to be 
known only to the fewest persons specifically designated by the Assistant Directors." Edwards (n.d.) also wrote that he hoped that a "concurrence of opinion may be arrived at on a plan which can then be submitted for the required covert administrative support." A subsequent memo also titled Project BLUEBIRD, written by Edwards to CIA Director Hillenkoetter has two dates, April 5, 1950 and a handwritten date of April 20, 1950. In the memo, Edwards requested direct approval from Hillenkoetter for the BLUEBIRD project due to its "extreme sensitivity and covert nature" (Director of Central Intelligence 1950). Hillenkoetter stamped his approval on the BLUEBIRD project for the amount of $\$ 65,515.00$, which included salaries for two psychiatrists, drugs, a polygraph, and security.

One heavily redacted memo dated July 2, 1951 establishes that select PSB members had knowledge of BLUEBIRD. Located in the MKULTRA collection at Black Vault, the memo "lists all persons briefed on BLUEBIRD." In this blacked-out memo, Gen. Walter Bedell Smith, first chairman of the PSB who relieved Rear Adm. Roscoe H. Hillenkoetter as DCI (an agency member of the PSB when it was established), is visibly marked as briefed on the BLUEBIRD (Memorandum 1951). Other names shine through on the redacted memo: J.H. Alberti, Allen W. Dulles, and Richard Helms were briefed, as was Frank Wisner of OPC ${ }^{38}$ and Col. Sheffield Edwards, CIA's Chief of Inspection and Security ${ }^{39}$; Lyman B. Kirkpatrick, Jr., CIA Inspector General, and John S. Earman, who as previously discussed, was to become 
Secrecy and Society, Vol. 1, No. 2 [2018], Art. 6

CIA IG, were briefed. ${ }^{40}$ Hillenkoetter, who clearly approved BLUEBIRD, and a number of other individuals listed on the memo including Earman, followed protocols of concealment and compartmented communications in restricting the larger PSB and agency members to the Board from learning of the project. Based on this memo, we can identify too that Mr. Earman, true to secrecy's embodiment in compartmentalization, remained silent on BLUEBIRD in his 1963 MKULTRA report.

In a memorandum dated March 17, 1951, Assistant Deputy for Inspection and Security Col. Sheffield Edwards (1951) laid out the compartmented "special handling" procedures for documents on the BLUEBIRD program. BLUEBIRD documents were classified TOP SECRET and hand carried from one office to another "on a EYES ONLY basis." Documents, wrote Edwards (1951), could be classified as SECRET if they did "not specify the true purpose of the program." In addition to these security measures, a "control list" was established "for all persons who need to know and are briefed on this project" (Edwards 1951). It is not clear if any PSB staff appeared on the control list, nor is it certain if the list remains classified.

The redacted July 25, 1951 memo titled Meeting with IAC Representatives of Project BLUEBIRD (1951) concerns "protection for our personnel against Soviet interrogation techniques." ${ }^{\prime 1}$ The IAC, or the Intelligence Advisory Committee (1948-1954), grew from the Intelligence Advisory Board and was chaired by the DCI. Members included 
interdepartmental intelligence staff from State, the Atomic Energy Commission, Joint Chiefs, Army, Navy, and Air Force (Warner 1994; Keane and Warner 2007). ${ }^{42}$ There are several compelling things about the IAC memo: first, the exclusion of PSB staff, and two, the briefing was given by the previously mentioned Mr. J.H. Alberti, who presented information on a "Navy research effort" at Bethesda that began in 1947 - possibly Project Chatter. ${ }^{43}$ Mr. Alberti, that is Jack Henry Alberti, was a senior interrogator in the Office of Naval Intelligence and portrayed in the WWII-era Naval Inspector General's report as a less than professional officer. The report, which outlined the debriefing and interrogations of captured German submarine personnel at the Navy Yard, Portsmouth, New Hampshire, describes Alberti as "an intelligence official...dressed as a lieutenant commander, USN, [sic who] had interrogated the U-873 commanding officer, Lieutenant Commander Steinhoff, in a humiliating manner" (Watterson 2014, 201). Steinhoff is described as "bloody and bruised" after two days of interrogation, and shortly after committed suicide (Paterson 2009, 60). Alberti was also accused of distributing "looted decorations and personal and public property to Prison personnel as he saw fit" (Naval Inspector General 1945). The Navy IG concluded that Alberti's actions were in "direct violation of the Geneva Convention and the Chief of Naval Operations' directives" (Naval Inspector General 1945). Other reports of prisoner abuse included the captured crew of U-546 (Paterson 2009, 55). Alberti responded to the 
Secrecy and Society, Vol. 1, No. 2 [2018], Art. 6

charges that he had not been involved in any "irregularities" (Paterson 2009, 61-63), but it remains that he came to the IAC meeting under a dark star, and the larger PSB was unaware of the briefing and Alberti's background.

Additional information on the relationship between the PSB and BLUEBIRD is revealed in a May 13 memo from H. Marshall Chadwell (1953), Assistant Director, CIA's Office of Scientific Intelligence, to DCI Allen W. Dulles. The memo, entitled Briefing for the Psychological Board, discusses secret research

on a drug called "Seramin" (Lysergic Acid Diethylsmide, commonly called LSD). This drug is manufactured by Sandoz, Inc., Switzerland, and has been exported to the USSR. It causes temporary mental derangement.

The memo advised DCI Dulles that

If one of our high government officials shows signs of a changed personality, steps should be taken to have him "confined to quarters" for at least $2 \mathrm{~h}$ hours, as the drug above mentioned dissipates its effect in that period of time, provided no additional doses are administered. This, consequently, means that the food and liquids during this $2 \mathrm{~h}$ hour period must be very carefully watched.

In this memo, Chadwell (1953) briefed Dulles on "brain washing" and a "group of drugs which temporarily alter personality," and went onto recommend that "it is felt that it is inadvisable to make any general release of information in regard to drugs with relation to 'brain washing.'" Attached to Chadwell's memo is a "Suggested Briefing" that perfectly illustrates how secrecy is partnered to compartmentalization. Chadwell (1953) cautions Dulles that 
In our opinion, the Psychological Strategy Board and the Intelligence Advisory Committee in executive session should be briefed only in general terms, with no reference to the specific drug described, and "no publicity" should be stressed. The attached memorandum is a suggested outline for your briefing of PSB. This matter has been coordinated with Col. Sheffield Edwards and Dr. Willis Gibbons.

As late as November 1953, CIA continued its planning of BLUEBIRD programmatic activities, which included "experimentation with the hypospray as a surreptitious speech inducing means on unwilling subjects without the use of polygraph or further intravenous injection of drugs" (Central Intelligence Agency 1953b). ${ }^{44}$

The above-cited memos indicate the PSB was largely removed from full awareness of BLUEBIRD activities. Moreover, it remains uncertain if select PSB members had knowledge or involvement with the BLUEBIRD Control Board (Central Intelligence Agency 1953a) or the CIA-funded Society for the Investigation of Human Ecology, which a redacted cable describes as a "cover mechanism" for numerous projects (Central Intelligence Agency 1977a). ${ }^{45}$ It is also uncertain if the IAC had full access to BLUEBIRD information.

\section{Project ARTICHOKE (1949-1956?)}

ARTICHOKE is "the Agency cryptonym for the study and/or use of 'special' interrogation methods and techniques. These 'special' interrogation methods have been known to include the use of drugs and chemicals, hypnosis, and 'total isolation,' a form of psychological harassment" (Central 
Secrecy and Society, Vol. 1, No. 2 [2018], Art. 6

Intelligence Agency 1975a; 1952). Polygraph testing was also the subject of study within the ARTICHOKE program (Central Intelligence Agency 1955).

In his testimony before the Select Committee on Intelligence (1977, 43), DCI Admiral Stansfield Turner places ARTICHOKE "for a few years beginning in 1949 we assessed foreign research on LSD under Project ARTICHOKE because of concern that such drugs might be employed against Agency and other U.S. personnel." Other accounts date Project ARTICHOKE operating from 1951-1955 (Albarelli 2009, 227, Scheflin and Opton 1978, 210). However, the Church Committee pinpoints different dates for the inception and conclusion of the program:

In August 1951, the project was renamed ARTICHOKE...information about Project ARTICHOKE after the fall of 1953 is scarce. The CIA maintains that the project ended in 1956, but evidence suggests that Office of Security and Office of Medical Services use of "special interrogation" techniques continued for several years thereafter. (Senate Select Committee to Study Governmental Operations with Respect to Intelligence Activities 1976a, 387-388) ${ }^{46}$

The Church Committee identified that CIA's Office of Scientific Intelligence (OSI) "initially led BLUEBIRD/ARTICHOKE efforts." In 1952, responsibility for ARTICHOKE was transferred from OSI to the Inspection and Security Office (I\&SO), the predecessor to the Office of Security (Senate Select Committee to Study Governmental Operations with Respect to Intelligence Activities 1976a, 388; Central Intelligence Agency 1975a). A January 1952 memo credits the I\&SO, which organized "permanent teams to apply ARTICHOKE methods" to assist the OSI in its coordination of 
ARTICHOKE activities (Central Intelligence Agency 1952a). OSI was the "focal point for all information from the Army, Navy, Air Force, Veterans Administration, CIA FBI, Treasury Department, and private contractors (Central Intelligence Agency 1952a). The January memo reports that ARTICHOKE's focus was the "evaluation and development of any method by which we can get information from a person against his will and without his knowledge" (Central Intelligence Agency 1952a). In the memo, CIA bemoaned the "failure to get scientifically trained personnel in key positions in the project" and posed the question, "How could we counter such methods if they were used against us?"

A February 1952 memo further outlines the ARTICHOKE program "to develop electroshock and hypnosis techniques, drug techniques, neurosurgical techniques, psychological techniques based upon work [redacted] and develop rapid screening and selection techniques" (Research Projects 1952). ARTICHOKE operations also included studies for inducing "triggers" for targeted assassination. ${ }^{47}$

Several memos suggest that while the PSB was generally aware of brainwashing claims, ARTICHOKE particulars are muted in official memorandums. For example, at a February 19, 1953 PSB meeting, Allen Dulles discusses a letter he received from Secretary of Defense Charles E. Wilson on the subject of publicly addressing Communist indoctrination and the alleged confessions of U.S. servicemen held in Korea. The minutes state: 
Secrecy and Society, Vol. 1, No. 2 [2018], Art. 6

Mr. Wilson's letter on "brain washing" was discussed. Mr. Stassen expressed the view that a press release is not the best way to handle this, and suggested instead that a leading doctor or scientist might read a paper on the subject at a scientific conference, thus reducing Government attribution and still gaining wide publicity. Mr. Dulles indicated that CIA would get together everything available on the subject. ${ }^{48}$ (Central Intelligence Agency 1953c)

In his letter, Secretary Wilson (1953a) not only shared the Department of Defense's disquietude over interrogation techniques used by Chinese Communists, but proposed a "counter propaganda" campaign. Wilson's memo is remarkable for its creative use of language, such as "mind murder" and "mendicide," synonyms for psychological techniques to alter cognition, judgment, and behavior. Wilson reframes interrogation methods that result in "brainwashing" as a "'new' form of war crime":

In this connection I am enclosing copies of a proposed press release and background information summary developed in the Department of the Army, as well as a preliminary study outlining a possible counter propaganda program based upon charging the Communists with a 'new' form of war crime, and a new refinement in atrocity techniques; namely, "mind murder" or mendicide. (Wilson 1953a) ${ }^{49}$

A heavily redacted memo records a subsequent PSB meeting on February 26. In this memo, DCI Dulles reported the Board discussed Wilson's press release The Utilization of Captured American Personnel as Vehicles of Communist Propaganda on the "brain washing question." The meeting resulted in a request that Dulles contact Detlev Bronk, then president of Johns Hopkins University, "to see whether he would head up a panel of private consultants experienced in the appropriate fields which would issue a 
statement in lieu of the Pentagon press release" (Central Intelligence Agency 1953d). Out of this discussion, the Board formed an Interdepartmental Working Committee composed of PSB members and personnel from CIA, Defense, and State that met March 3 to strategize on how to address Wilson's proposed press release. In a calculated March memo from Dulles to the Under Secretary of State and the Deputy Secretary of Defense, the DCI challenges the efficacy of "brainwashing" and/or "mind control." Dulles (1953) writes that

A quick search in CIA shows little scientific evidence to support brainwashing. There is rather massive evidence in the form of case reports and circumstantial evidence which leads to the conclusion that it is not a difficult matter, given the time, to force almost anyone to make an inaccurate statement, provided that the time at which the statement is to be made can be controlled and the individual is not required to continue his willingness to lie for a long period.

One wonders if Dulles had openly discussed these particular CIA "findings" publicly if the brainwashing craze of the 1950s would have taken hold so firmly in the American psyche. Instead, fear and paranoia over Communist brainwashing became entrenched as conspiracy during the Cold War (Marks 1979; also see Carruthers 1998).

Additional memos from 1953 include a report on the coordination of ARTICHOKE activities within the U.S. with the participation of the USDA ("enlisted to speed up the bringing into the United States botanicals") and FDA, who was on standby to lend its labs and testing facilities "when and if necessary" (Central Intelligence Agency1953a). At this time, it remains 
uncertain if the PSB had knowledge of these domestic activities or the use of ARTICHOKE techniques on individuals held in federal prisons (Central Intelligence Agency 1953e); it's also not clear if PSB had knowledge of the ARTICHOKE Committee, which maintained a compartmented relationship with personnel at Camp Detrick, and met once or twice a year "to discuss questions involving behavioral drugs" (Chamberlain 1975, 1124).

In the Church Committee's questioning of Dr. Sidney Gottlieb as to "why information on the surreptitious administration of LSD" was not shared with the ARTICHOKE Committee, the scientist responded "I imagine the only reason would have been a concern for broadening the awareness of its existence" (Senate Select Committee to Study Governmental Operations with Respect to Intelligence Activities $1976 a, 410) .{ }^{50}$ As this mini-case study illustrates, perhaps the same "concern" restricted information sharing between the PSB and CIA.

\section{Project MKULTRA (1950-1970?)}

Project MKULTRA is described as a R\&D project involving the CIA and various branches of the military (Senate Committee on Human Resources 1977). ${ }^{51}$ The "MKULTRA charter" included the investigation of "radiation, electroshock, various fields of psychology, psychiatry, sociology, and anthropology, graphology, harassment substances, and paramilitary devices and materials" (Earman 1963,4). It is possible that MKULTRA included other subjects of intelligence interest to CIA. According to the testimony of Dr. 
Charles F. Geschickter of the CIA and NIH-funded Geschickter Fund for Medical Research, research was conducted on amnesia induced by concussion, as well as "the use of radar to put monkeys to sleep...instead of Mickey Finn, they could put them under with radar directed toward the monkey brain" (Senate Committee on Human Resources 1977, 90). ${ }^{52}$ DCI Allen Dulles approved the MKULTRA project based on Richard Helms' recommendation that "security considerations precluded handling the project through usual contractual agreements" (Senate Select Committee to Study Governmental Operations with Respect to Intelligence Activities 1976a, 4056). "Established" CIA audit procedures were waived for MKULTRA (Earman $1963,8) \cdot{ }^{53}$

One account situates the inception of the MKULTRA program in 1950, "motivated largely in response to alleged Soviet, Chinese, and North Korean uses of mind-control techniques on U.S. prisoners of war in Korea" (Advisory Committee on Human Radiation Experiments 1995a, 185). However, the Church Committee notes that "because MKULTRA records were destroyed, it is impossible to reconstruct the operational use of MKULTRA materials by the CIA overseas; it has been determined that the use of these materials abroad began in 1953, and possibly as early as 1950" (Senate Select Committee to Study Governmental Operations with Respect to Intelligence Activities 1976a, 391). In testimony before the Senate Committee on Human Resources, Subcommittee on Health and Scientific Research (1977), Sidney 
Secrecy and Society, Vol. 1, No. 2 [2018], Art. 6

Gottlieb shared that "several research inquiries - which much later came to be organized under the cryptonym MKULTRA - were begun around 1952." Still another account reports the approval of the program by DCI Dulles on April 13, 1953 "along the lines proposed by ADDP Helms" (Senate Select Committee to Study Governmental Operations with Respect to Intelligence Activities 1976a, 390). CIA IG John S. Earman (1963) reports the program having a "ten year life," that is, from 1953-1963.

The Church Committee discusses MKULTRA in ratio with MKDELTA, with MKULTRA as a R\&D arm, while MKDELTA "denotes the DD/P" (Senate Select Committee to Study Governmental Operations with Respect to Intelligence Activities 1976a, 391; Earman 1963; Marks 1979, 61). ${ }^{54}$ MKDELTA was "established by CIA in October, 1952, for the use of biochemicals in clandestine operations," and "may never have been implemented operationally" (General Counsel for the Department of Defense 1977).

MKULTRA was renamed MKSEARCH in 1964 to continue as a testbed for "biological, chemical and radioactive material systems and techniques for producing predictable human behavioral and/o physiological changes in support of highly sensitive operational requirements" (Helms 1964). In changing the cryptonym for the project, Helms (1964) wrote that "after eleven years of experience with the MKULTRA mechanism, it is my belief that the basic reasons for requesting waiver of standardized administrative controls over these sensitive activities are as valid today as they were in 
April 1953." In 1977, Adm. Turner testified that Geschickter continued his research on amnesia and sleep-producing drugs under the MKSEARCH program through July, 1967 at Georgetown University Hospital (Senate Select Committee on Intelligence 1977).

At the September 21 Senate Committee on Human Resources hearing, Sen. Edward M. Kennedy described MKULTRA, MKSEARCH, and MKCHICKWIT55 as being "turned on and turned off in a never-ending web, at least for that 20-year period of time" (Senate Committee on Human Resources 1977, 122). Kennedy characterized these programs as

various kinds of drug testing assuming different names; it is the MKULTRA, MKSEARCH, MKCHICKWIT, MKOFTEN. ${ }^{56}$ Whether they have "MK" before. them or not, there is a continuing program for a period of some 21 years, up to 1973, with unwitting and, then, witting subjects. (Senate Committee on Human Resources 1977, 129)

As the PSB was not formally dissolved until September 1953, here I speculate that it is possible certain PSB members - Dulles aside - had awareness of these programs, and national security secrecy drove informational selectivity and circle of trust.

\section{Where the Past is the Present}

When I began this project some seven years ago, my research questions were simple: I was curious as to PSB's place within the history of U.S. psychological warfare efforts, its interactions with CIA under NSC 10/5, and knowledge of the Agency's three clandestine programs. During the 
course of my research, I discovered the PSB did not uniformly offer approval to CIA for its clandestine and covert operations, and indeed, had uneven knowledge of the BLUEBIRD, ARTICHOKE, and MKULTRA programs. Consequently, these programs went unchallenged by the press, public, Congress, and perhaps sitting presidents.

In addition to these findings, I stumbled on conflicting dates for the inception and termination of the BLUEBIRD, ARTICHOKE, and MKULTRA programs, which suggest alterations to the current historical record. True to secrecy as a parallel form of government, I identified institutional barriers that influence a comprehensive telling of the PSB and in general, the Intelligence Community's clandestine and covert programs. These barriers make history-building an often speculative, incomplete process. To this end, my goal in documenting the PSB's knowledge of CIA's BLUEBIRD, ARTICHOKE, and MKULTRA is to encourage direct engagement with the declassified archive as to make the invisible visible. Through encounters with the past, we are better able to confront those elements of the administrative apparatus based in secrecy and deception that lead to the fracture of informed consent and infringe on the "right to responsible history" (De Baets 2008, 164).

Sen. Edward M. Kennedy's measured comments during the Project MKULTRA hearings perfectly sum up the subterranean, rogue nature of the three CIA programs discussed in this article: 
The intelligence community of this Nation, which requires a shroud of secrecy in order to operate, has a very sacred trust from the American people. The CIA's program of human experimentation of the fifties and sixties violated that trust. It was violated again on the day the bulk of the agency's records were destroyed in 1973. It is violated each time a responsible official refuses to recollect the details of the program. The best safeguard against abuses in the future is a complete public accounting of the abuses of the past. (Senate Select Committee on Intelligence 1977,3 )

Sen. Kennedy's words are important for today's world, if for only the reminder that respect for civil liberties and human rights are the backbone of just societies, not secrecy. This is not to say the use of national security secrecy isn't essential to the "pursuit of happiness" and security; quite the contrary. Secrecy "of various kinds is sometimes justified and even desirable in a democracy" (Thompson 1999, 192). But the use of secrecy is "justified only under carefully specified conditions, which ensure that the secrecy itself is subject to democratic accountability" (Thompson 1999, 192).

As this case study of the PSB suggests, the "disfunctional excesses" of CIA deeply conflicts with the "norm of candor and sincerity" (Friedrich 1972, $176,179)$. Some sixty odd years after the dissolution of the PSB, we are left to conjecture if the Board might have exercised critical oversight of CIA had it had a stronger interpretation of NSC $10 / 5$ and been a party to greater information sharing in the areas of clandestine and covert actions. We are instead left to further disentangle this research problem from the [redacted] archive. 
The author greatly thanks archivist Randy Sowell, Harry S. Truman Library and Museum, archivist Mary Burtzloff and Michelle Kopfer, Declassification Staff, Dwight D. Eisenhower Library and Museum for their longstanding research support and guidance.

\section{References}

Action by Psychological Strategy Board relative to problem of caring for refugees from Iron Curtain countries. 1951. October 25, CIA-RDP8001065A000200050053-3. https://www.cia.gov/library/readingroom/document/cia-rdp80$\underline{01065 a 000200050053-3}$

Admiral Kirk's new post. 1952. The New York Times, August 15.

Advisory Committee on Human Radiation Experiments. 1995a. Final report. October, DE96000437. Springfield, VA: NTIS.

https://ntrl.ntis.gov/NTRL/

---. 1995b. Memorandum: Post-World War II recruitment of German scientists - Project Paperclip. April 5.

http://nsarchive.gwu.edu/radiation/dir/mstreet/commeet/meet13/brief1 3/tab f/br13f3.txt

Albarelli Jr., H.P. 2009. A terrible mistake: The murder of Frank Olson and the CIA's Cold War experiments. Walterville, OR: Trine Day.

---. 2013. A secret order: Investigating the high strangeness and synchronicity in the JFK assassination. Walterville, OR: Trine Day. 
Anderson, Frederick L. 1955. Psychological aspects of United States strategy panel report. November 29, CIARDP86B00269R000300120002-3. https://www.cia.gov/library/readingroom/document/ciardp86b00269r000300120002-3

Barnes, Trevor. 1982. The secret Cold War: The C.I.A. and American foreign policy in Europe 1946-1956. Part II. The Historical Journal 25, no. 3: 649-670.

Barrett, Edward W. 1950. Note from Mr. Barrett: Proposed announcement on establishment of a national psychological strategy board. August 14, CIA-RDP80-01065A000500120053-2. https://www.cia.gov/library/readingroom/document/cia-rdp8001065a000500120053-2

Becker, Loftus E. 1953. Comment on substance of draft report prepared by Henry Loomis of the PSB staff, entitled Report on social science research in Cold War operations. May 19, CIARDP80R01731R003300090003-8. https://www.cia.gov/library/readingroom/document/ciardp80r01731r003300090003-8

Benedictus, Leo. 2016. Invasion of the troll armies: From Russian Trump supporters to Turkish state stooges." The Guardian, November 6. https://www.theguardian.com/media/2016/nov/06/troll-armies-socialmedia-trump-russian

Blanton, Thomas, and Peter Kornbluh. 2014. Prisoner abuse: Patterns from the past. National Security Briefing Book, February. http://nsarchive.gwu.edu/NSAEBB/NSAEBB122/

Briefing for the Psychological Strategy Board. 1953. May 13, CIARDP80R01731R003300340002-1. https://www.cia.gov/library/readingroom/document/ciardp80r01731r003300340002-1

---. Briefings on research in the social sciences of use to Psychological Strategy Board planning and operations. 1952. September 11, CIA- 
RDP80-01065A000500100115-5.

2017.https://www.cia.gov/library/readingroom/document/cia-rdp80$\underline{01065 a 000500100115-5}$

Brown, Richard E. 2007. Alfred McCoy, Hebb, the CIA and torture. Journal of the History of the Behavioral Sciences 43, no. 2: 205-213.

Brown, Robin. 2003. Spinning the war: Political communications, information operations and public diplomacy in the war on terrorism. In War and the media: Reporting conflict 24/7, edited by Daya Kishan Thussu and Des Freedman, 87-100. Thousand Oaks: SAGE publications.

Buchanan, Tom. 2001. The courage of Galileo: Joseph Needham and the germ warfare allegations in the Korean War." History 86 no. 284: 503522.

Buckman, John. 1977. Brainwashing, LSD, and CIA: Historical and ethical perspective. International Journal of Social Psychiatry 23, no. 1: 8-19.

Cannon, Martin. 1992. Mind control and the American government. Lobster, 23: 1-23.

Carruthers, Susan L. 1998. 'The Manchurian Candidate' (1962) and the Cold War brainwashing scare. Historical Journal Of Film, Radio \& Television 18, no. 1: 75.

Central Intelligence Agency. 1951a. Intelligence support for psychological warfare. March 30, CIA-RDP80R01731R003400100019-8. https://www.cia.gov/library/readingroom/document/ciardp80r01731r003400100019-8

. 1951b. Intelligence support for psychological warfare. June 21, CIA RDP80R01731R003500180009-0. https://www.cia.gov/library/readingroom/document/ciardp80r01731r003500180009-0

. 1951c. Memorandum for the OSD Classified Mail and Records: 
Subject Destruction of classified material. October 30,CIA-RDP8301042R000800010005-9.

https://bkofsecrets.files.wordpress.com/2017/02/bluebird artichoke de structionofdocs.pdf

. 1951d. Memorandum for: Psychological warfare organizations. May

28, CIA-RDP80R01731R003500180011-7.

https://www.cia.gov/library/readingroom/document/cia-

rdp80r01731r003500180011-7

. 1951e. Memorandum for the DDCI: CIA participation in the

Psychological Strategy Board. September 7, CIA-RDP80-

01065A000600010044-3.

https://www.cia.gov/library/readingroom/document/cia-rdp80-

01065a000600010044-3

. 1951f. Preliminary staff meeting national psychological strategy

board (NPSB). May 8, 1951f, CIA-RDP80R01731R003400010035-0.

https://www.cia.gov/library/readingroom/document/cia-

rdp80r01731r003400010035-0

. 1951g. Psychological warfare organizations. May 28, CIA-

RDP80R01731R003500180011-7.

https://www.cia.gov/library/readingroom/document/cia-

rdp80r01731r003500180011-7

. 1952a. Memorandum for: Chief medical staff subject: Project

Artichoke evaluation of the I\&SO role. January 25.

https://bkofsecrets.files.wordpress.com/2017/02/projectartichoke evalu

ationmemo.pdf

. 1952b. Memorandum for chiefs, area, and staff divisions. Subject:

Psychological Strategy Board. April 8, CIA-RDP80-

01065A000600020103-6.

https://www.cia.gov/library/readingroom/document/cia-rdp80-

01065a000600020103-6.

---. 1952c?. Memorandum for: Col. Sands. Subject: Psychiatric warfare. 
August 1, CIA-RDP80-01065A000600020044-2.

https://www.cia.gov/library/readingroom/document/cia-rdp80-

01065a000600020044-2

---. 1952d. Psychological Strategy Board: Mr. Gray's report to the president, dated 22 February 1952. March 6, CIA-

RDP80R01731R003300180044-3.

https://www.cia.gov/library/readingroom/document/cia-

rdp80r01731r003300180044-3

. 1953a. ARTICHOKE conference. April 16. CK2349365024, U.S.

Declassified Documents Online.

. 1953b. BLUEBIRD Project. November 9. CK2349398323, U.S.

Declassified Documents Online.

. 1953c. Memorandum for the record: PSB meeting February 19, 1953.

February 24, CIA-RDP80R01731R003300190041-5.

https://www.cia.gov/library/readingroom/document/ciardp80r01731r003300190041-5

. 1953d. Memorandum for the record: PSB meeting February 26,

1953. March 2, CIA-RDP80R01731R003300190040-6.

https://www.cia.gov/library/readingroom/document/cia-

rdp80r01731r003300190040-6

. 1953e. Proposed research (Bluebird-Artichoke). September 23.

CK2349398477, U.S. Declassified Documents Online.

. 1954. Security, ARTICHOKE report. January 22, DOC_0000140399.

http://www.foia.cia.gov/sites/default/files/document conversions/89801 LDOC 0000140399.pdf/

. 1955. ARTICHOKE operation, 20-23 January 1955. chief, Security Research Staff. February 16. CK2349402470, U.S. Declassified Documents Online. 
. 1975a. Memorandum for the record, Subject: Project ARTICHOKE. January 31. John Marks Collection.

http://nsarchive.gwu.edu/NSAEBB/NSAEBB54/st02.pdf

---. 1975b. Central Intelligence Agency statement before Subcommittee on Health Committee on Labor \& Public Welfare and Administrative Practice \& Procedure Subcommittee Committee on the Judiciary. November 7, CIA-RDP78-04163R000100100003-7. https://www.cia.gov/library/readingroom/document/cia-rdp7804163r000100100003-7

. 1977a. CABLE TO (sanitized) from director. August 3, CIARDP80M00165A000700140066-1. https://www.cia.gov/library/readingroom/document/ciardp80m00165a000700140066-1

---. 1977b. Memorandum for acting director of Central Intelligence: Newly discovered documents pertaining to the Agency's research and experimentation with drugs - Projects Artichoke and Bluebird. August 17, CIA-RDP81 00261R000300050003-5. https://www.cia.gov/library/readingroom/document/cia-rdp8100261r000300050003-5

---. n.d. (1953?). Memorandum for: The Under Secretary of State The Deputy Secretary of Defense. Subject: Brainwashing. CIARDP80B01676R002600130048-0. Accessed March 15, 2017. https://www.cia.gov/library/readingroom/document/ciardp80b01676r002600130048-0

Chadwell, H. Marshall. 1953. Briefing for the Psychological Strategy Board. May 13, CIA-RDP80R01731R003300340002-1. https://www.cia.gov/library/readingroom/document/ciardp80r01731r003300340002-1

Chamberlain, Donald F. 1976. CIA R\&D and testing of behavioral drugs. February 5, 1975. Senate Committee on Labor and Public Welfare, Subcommittee on Health. Biomedical and behavioral research, 1975: Joint hearings before the Subcommittee on Health of the Committee on Labor and Public Welfare and the Subcommittee on Administrative Practice and Procedure of the Committee on the Judiciary, on human- 
use experimentation programs of the Department of Defense and Central Intelligence Agency and S. 2515, to amend the Public Health Service Act to establish the president's commission for the protection of human subjects involved in biomedical and behavioral research, and for other purposes, 94-1, September 10, 12; and November 7, 1975. Washington, DC: Government Printing Office.

Chomsky, Noam. 1989. Necessary illusions: Thought control in democratic societies. Boston, MA: South End Press.

Clarke, Richard. 2017. Real Time with Bill Maher. June 30. Youtube, 1:50. https://www.youtube.com/watch?v=OCBJSmWY6nE

Commission on CIA Activities within the United States. 1975. Report to the president by the Commission on CIA Activities within the United States. June. Washington, DC: Government Printing Office. https://archive.org/details/reporttopresiden01unit

Commission on Protecting and Reducing Government Secrecy. 1997. Report of the Commission on Protecting and Reducing Government Secrecy: Pursuant to public law 236, 103rd Congress. Washington, DC: Government Printing Office. http://www.gpo.gov/fdsys/pkg/GPO- CDOC105sdoc2/content-detail.html

Conahan, Frank C. 1994. Human experimentation: An overview on Cold War era programs. Testimony before the Legislation and National Security Subcommittee, Committee on Government Operations, House of Representatives. U.S. General Accounting Office. T-NSIAD-94-266. http://www.gao.gov/products/T-NSIAD-94-266

Cook, Blanche Wiesen. 1984. First comes the lie: CD Jackson and political warfare. Radical History Review no. 31: 42-70.

Cook, Ralph E. 1983. The CIA and academe. Studies in Intelligence 27, no. 3: 33-42. https://www.cia.gov/library/readingroom/document/ciardp89g00720r000600620031-3 
Corke, Sarah-Jane. 2007. US covert operations and Cold War strategy: Truman, secret warfare and the CIA, 1945-53. New York: Routledge.

Craig, Horace S. Exploitation of communist BW charges. July 7, 1953, CIARDP80R01731R003300190004-6. https://www.cia.gov/library/readingroom/document/ciardp80r01731r003300190004-6

Cull, Nicholas J. 2009. Public diplomacy: Lessons from the past. CPD Perspectives, USC Center on Public Diplomacy and Figueroa Press. https://uscpublicdiplomacy.org/story/cpd-perspectives-publicdiplomacy-lessons-past

Cutler, Robert. 1956. The development of the National Security Council. Foreign Affairs 34, no. 3: 441-458.

Daugherty, William E., and Morris Janowitz (eds). 1958. A psychological warfare casebook. Tactics Division, Memorandum ORO-T-36C, March. Operations Research Office. Baltimore: Johns Hopkins University Press.

Davis II, Robert T. 2008. Cold War interagency relations and the struggle to coordinate psychological strategy. In The US Army and the interagency process: Historical perspectives: Proceedings of the Combat Studies Institute 2008 military history symposium, edited by Kendall D Gott; Michael G Brooks, 301-19. Fort Leavenworth, KA: US Army Combined Arms Center, Combat Studies Institute Press.

http://usacac.army.mil/cac2/cgsc/carl/download/csipubs/2008Symposiu m.pdf

De Baets, Antoon. 2008. Responsible history. New York: Berghahn Books.

De McLaurin, Ronald, Carl F. Rosenthal, and Sarah A. Skillings. 1976. The art and science of psychological operations: Case studies of military application. Washington, DC: American Institutes for Research, U.S. Department of Defense, Department of the Army.

Department of Defense. 1952. Literature as an anti-communist weapon (letter from W.H. Godel). January 17. CK2349302322, U.S. Declassified Documents Online. 
. 1952. W.H. Godel's memo to C. Tracy Barnes on NATO briefings for the PSB. January 21. CK2349059593, U.S. Declassified Documents Online.

Director of Central Intelligence. 1950. Project Bluebird. April 5, CIARDP83-01042R000800010003-1. https://www.cia.gov/library/readingroom/document/cia-rdp8301042r000800010003-1

Dr. Allen accepts strategy position: Leaves university presidency to succeed Gordon. The New York Times, November 23, 1951.

Drugs. n.d. Black Vault, Disk 2, DOC_0000190510. http://www.theblackvault.com/documentarchive/cia-mkultra-collection/

Dubljević, Veljko, and Eric Racine. 2017. Moral enhancement meets normative and empirical reality: Assessing the practical feasibility of moral enhancement neurotechnologies. Bioethics 31, no. 5: 338-348.

Dulles, Allen W. 1952. Coordination and routing of Papers for submission to the National Security Council. June 9, CIARDP86T00268R000800120073-3. https://www.cia.gov/library/readingroom/document/ciardp86t00268r000800120073-3

. 1953. Memorandum for: The Under Secretary of State, Deputy Secretary of Defense: Brainwashing. CIARDP80B01676R002600130048-0. https://www.cia.gov/library/readingroom/document/ciardp80b01676r002600130048-0

Earman, J.S. 1963. Memorandum for Director of Central Intelligence: Report of inspection of MKULTRA. July 26. CIA MKULTRA Collection, Black Vault, Disk 4, Folder 17748. http://www.theblackvault.com/documentarchive/cia-mkultra-collection/ 
Edwards, Sheffield. 1951. Memorandum: Subject Bluebird. March 17, CIA-RDP83-01042R000800010003-1. https://www.cia.gov/library/readingroom/document/cia-rdp8301042r000800010003-1

. n.d. Memorandum to assistant directors: Subject: Project

"BLUEBIRD. " CIA-RDP83-01042R000800010005-9. Accessed February 15, 2017.

https://bkofsecrets.files.wordpress.com/2017/02/bluebird artichoke de structionofdocs.pdf

Eisenhower, Dwight. D. 1953. Letter to Psychological Strategy Board from Dwight D. Eisenhower. March 5, CIA-RDP80R01731R000700450020-8. https://www.cia.gov/library/readingroom/document/ciardp80r01731r000700450020-8

Endicott, Stephen, and Edward Hagerman. 1998. The United States and biological warfare: Secrets from the early Cold War and Korea. Bloomington: Indiana University Press.

Falk, Stanley L. 1964. The National Security Council under Truman, Eisenhower, and Kennedy. Political Science Quarterly 79, no. 3: 403434.

Friedrich, Carl J. 1972. The pathology of politics: Violence, betrayal, corruption, secrecy, and propaganda. New York: Harper \& Row.

Gary, Brett. 1999. The nervous liberals: Propaganda anxieties from World War I to the Cold War. New York: Columbia University Press.

General Counsel for the Department of Defense. 1977. Memorandum for the Secretary of Defense: Experimentation programs conducted by the Department of Defense that had CIA sponsorship or participation and that involved the administration to human subjects of drugs intended for mind-control or behavior modification purposes. September 20. http://www.dod.mil/pubs/foi/Reading Room/NCB/02-A0846 RELEASE.pdf 
Goldman, Jan, and Susan Maret. 2016. Intelligence and information policy for national security: Key terms and concepts. Lanham, MD: Rowman and Littlefield.

Gough, Susan L. 2003. The evolution of strategic influence. Army War College, Carlisle Barracks, PA. USAWC Strategy Research Project. ADA420183. http://oai.dtic.mil/oai/oai? verb $=$ getRecord $\&$ metadataPrefix $=$ html\&identifier $=$ ADA420183

Government Attic. 2016. National Archives and Records Administration (NARA) database of the 3603 records identified as "withheld in full" in the John F. Kennedy Assassination records collection. January 21. http://www.governmentattic.org/19docs/NARAjfkAssassinationRecordsC ollWithheld 2016.pdf

Gray, Gordon. 1951. Suggested fiscal year 1953 budget estimate for the Psychological Strategy Board. October 17, CIARDP80R01731R003400020030-4. https://www.cia.gov/library/readingroom/document/ciardp80r01731r003400020030-4

. 1973. Oral history interview with Gordon Gray. Interviewer Richard D. McKinzie, June 18. https://www.trumanlibrary.org/oralhist/gray.htm

Halperin, Morton H., Jerry J. Berman, Robert L. Borosage, and Christine Marwick. 1976. The lawless state: The crimes of the U.S. intelligence agencies. New York: Penguin Books.

Helms, Richard. 1964. Memorandum for: Director of Central Intelligence: Subject sensitive research programs (MKULTRA). June. CK2349402573, U.S. Declassified Documents Online.

Hixson, Walter L. 1997. Parting the curtain: Propaganda, culture, and the Cold War, 1945-1961. New York: Macmillan.

Hourcle, Laurent R. 1993. Military secrecy and environmental compliance. New York University Environmental Law Journal 2: 316. 
Houston, Lawrence R. 1952. Legislative problems of the Psychological Strategy Board: Reference memorandum dated 5 January 1952 from Mr. Charles Norberg, Office of Coordination, Psychological Strategy Board. January 15, CIA-RDP57-00384R000100190024-7. https://www.cia.gov/library/readingroom/document/cia-rdp57$\underline{00384 r 000100190024-7}$

Hunt, Linda. 1991. Secret agenda: The United States government, Nazi scientists, and Project Paperclip, 1945 to 1990. New York: St. Martin's Press.

Implementation of the Presidential Directive of April 4, 1951, Establishing a national psychological strategy board. n.d. CIA-RDP8001446R000100140055-2. Accessed https://www.cia.gov/library/readingroom/document/cia-rdp80$\underline{01446 r 000100140055-2}$

Institute for Propaganda Analysis. 1937. "Announcement." Propaganda: A bulletin to help the intelligent citizen detect and analyze propaganda. 1, no.1: 1-12.

ISOO. 2016. Report to the president. National Archives and Records Administration. https://www.archives.gov/files/isoo/reports/2016annual-report.pdf

Jackson, C.D. 1953. Memo to Psychological Strategy Board. May 14, CIARDP80R01731R003300330008-6. https://www.cia.gov/library/readingroom/document/ciardp80r01731r003300330008-6

Jackson, William H. 1953. Report to the president by the President's Committee on International Information Activities. June 30. Foreign Relations of the United States, 1952-1954, National Security Affairs vol. II, Part 2. https://history.state.gov/historicaldocuments/frus1952$\underline{54 \mathrm{v} 02 \mathrm{p} 2 / \mathrm{d} 370}$

Jacobsen, Annie. 2014. Operation Paperclip: The secret intelligence 
program that brought Nazi scientists to America. New York: Little, Brown and Company.

Johnson, Charles E. 1951. Psychological Strategy Board: Agenda. August 13, CIA-RDP80R01731R003400010015-2.

https://www.cia.gov/library/readingroom/search/site/CIA-

RDP80R01731R003400010015-2

Johnston, Kilbourne. 1951. Recommendation of position to be taken by the DCI regarding draft of February 19, 1951 proposing establishment of a psychological strategy board. February 23, CIA-

RDP80R01731R003400010009-9.

https://www.cia.gov/library/readingroom/document/ciardp80r01731r003400010009-9

Keane, Douglas, and Michael Warner, eds. 2007. The intelligence community 1950-1955: Foreign Relations of the United States. Washington, DC: Government Printing Office, Department Of State. https://history.state.gov/historicaldocuments/frus1950-55Intel

Krishnan, Armin. 2017. Military neuroscience and the coming age of neurowarfare. New York: Routledge.

Lay Jr, James S. 1951. A report to the National Security Council by the executive secretary. October 23. http://orchestratingpower.org/Covert.html

Lilly, Edward P. 1951. The development of American psychological operations 1945-1951. December 19, CIARDP86B00269R000900020001-9. https://www.cia.gov/library/readingroom/document/ciardp86b00269r000900020001-9

Linebarger, Paul M. A. 1954. Psychological warfare. Washington, DC: Combat Forces Press.

Lippmann, Walter. 1929 [1922]. Public opinion. New York: Macmillan Co, 
List of Psychological Strategy Board documents destroyed. 1952. September 22. CK2349327709, U.S. Declassified Documents Online.

Little, Wendell E. 1954. White House strategy-making machinery 1952, 1954. Maxwell Air Force Base, Air War College, Air University.

Loftus, John. 2010. America's Nazi secret: An insider's history. Waterville, OR: Trine Day.

Lord, Carnes. 1998. The past and future of public diplomacy. Orbis 42, no. 1 (1998): 49-73.

Lucas, Scott. 1996. Campaigns of truth: The Psychological Strategy Board and American ideology, 1951-1953. The International History Review 18, no. 2: 279-302.

. 1999. Freedom's war: The American crusade against the Soviet Union. NYU Press.

McCoy. Alfred W. 2007. A question of torture: CIA interrogation, from the Cold War to the war on terror. Metropolitan Books/Henry Holt and Co.

Macdonald, Scot. 2007. Propaganda and information warfare in the twenty-first century: Altered images and deception operations. New York: Routledge.

McWilliams, W.J. 1953. Handbook of Psychological Strategy Board functions and procedures. January 1, CIARDP80R01731R002600300001-4. https://www.cia.gov/library/readingroom/document/ciardp80r01731r002600300001-4

Markon, Jerry. 2010. No charges in destruction of CIA videotapes, Justice Department says. The Washington Post, November 9. http://www.washingtonpost.com/wpdyn/content/article/2010/11/09/AR2010110904106.html 
Marks, John D. 1979. The search for the "Manchurian candidate." New York: Times Books.

Meeting with IAC representatives of Project Bluebird: Memorandum for the file. 1951. July 25.

https://bkofsecrets.files.wordpress.com/2017/02/memo1951 color.pdf

Memorandum For. 1951. July 2, Black Vault, Disk 2, DOC_0000144813. http://www.theblackvault.com/documentarchive/cia-mkultra-collection/

Memorandum For: Acting Assistant Director for Policy Coordination. Subject: possible interest of the Psychological Strategy Board in psychological warfare research. 1951. July 30, CIA-RDP8300036R001100170019-1.

https://www.cia.gov/library/readingroom/document/cia-rdp83$\underline{00036 r 001100170019-1}$

Memorandum For: Chief, PY, Subject: Comments on specific questions to be incorporated in the Report to National Security Council by the Psychological Strategy Board. 1952. July 11, CIA-RDP8001065A000400020036-3. https://www.cia.gov/library/readingroom/document/cia-rdp80$\underline{01065 a 000400020036-3}$

Memorandum For: Letters from Messrs. Kyes and Smith re C. D. Jackson's draft letter to Mr. Nelson Rockefeller.1953. April, CIARDP80R01731R003300190017-2. https://www.cia.gov/library/readingroom/document/ciardp80r01731r003300190017-2

MKULTRA. 1979. September 7, CIA-RDP86-00114R000100080003-9. https://www.cia.gov/library/readingroom/document/cia-rdp86$\underline{00114 r 000100080003-9}$

MKULTRA briefing book. n.d. Black Vault, Disk 2, DOC_0000190090. Accessed January 11, 2017. http://www.theblackvault.com/documentarchive/cia-mkultra-collection/ 
Molander, Roger C., Andrew S. Riddile, and Peter A. Wilson. 1996. Strategic information warfare: A new face of war. MR-661-OSD. National Defense Research Institute, RAND. https://www.rand.org/content/dam/rand/pubs/monograph_reports/200 5/MR661.pdf

Montague, Ludwell Lee. 1992. General Walter Bedell Smith as director of Central Intelligence, October 1950-February 1953. University Park, PA: Pennsylvania State University Press.

Moreno, Jonathan D. 1996. "The only feasible means": The Pentagon's ambivalent relationship with the Nuremberg Code. Hastings Center Report 26, no. 5: 11-19.

. 2004. DARPA on your mind. Cerebrum: The Dana Forum on Brain Science 6, no. 4: 91-94.

. 2012. Mind wars: Brain science and the military in the twenty-first century. New York: Bellevue Literary Press.

Mumford, Lewis. 1970. The pentagon of power. New York: Harcourt Brace Jovanovich.

Nakamura, Kennon H., and Matthew C. Weed. 2009. U.S. public diplomacy: Background and current issues. CRS Report for Congress R40989, December 18. https://fas.org/sgp/crs/row/R40989.pdf

Parry-Giles, Shawn J. 1996. Camouflaged" propaganda: The Truman and Eisenhower administrations' covert manipulation of news. Western Journal of Communication 60, no. 2: 146-167.

President's Committee on International Information Activities. 1953. Report to the president. June 30, DOC 0000476939. https://www.cia.gov/library/readingroom/search/site/0000476939

Price, David, H. 1998. Cold War anthropology: Collaborators and victims of 
Secrecy and Society, Vol. 1, No. 2 [2018], Art. 6

the national security state. Identities Global Studies in Culture and Power 4, no. 3-4: 389-430.

---. 2007a. Buying a piece of anthropology, part I: Human ecology and unwitting anthropological research for the CIA. Anthropology Today 23, no. 5: 8-13.

---. 2007b. Buying a piece of anthropology, part II: The CIA and our tortured past. Anthropology Today 23, no. 5: 17-22.

---. 2016. Cold War anthropology: The CIA, the Pentagon, and the growth of dual use anthropology. Durham: Duke University Press.

Myers, Thomas I., Donald B. Murphy, Seward Smith, and S. James Gofford. 1966. Experimental studies of sensory deprivation and social isolation. Technical Report 66-8, AD0636478. Human Resources Research Office, George Washington University. http://www.dtic.mil/docs/citations/AD0636478

National Security Council. 1951. Actions taken by the National Security Council on the scope and pace of covert operations. October 23. CIARDP80-01065A000140043-1, https://www.cia.gov/library/readingroom/document/cia-rdp8001065a000500140043-1

Naval Inspector General. 1945. Irregularities connected with the handling of surrendered German submarines and prisoners of war at the Navy Yard, Portsmouth, New Hampshire - investigation of. June 19. http://www.uboatarchive.net/U-873A/U-873NIGReport.htm

Paddock Jr, Alfred H. 1982. U.S. Army special warfare. Its origins: psychological and unconventional warfare, 1941-1952. ADA118758. Washington, DC: National Defense University. http://oai.dtic.mil/oai/oai? verb $=$ getRecord \&metadataPrefix $=$ html\&identifier $=$ ADA118758

Paterson, Lawrence. 2009. Black flag: The surrender of Germany's U-Boat Forces on Land and at Sea. Barnsley: Seaforth. 
Pross, Christian. 1991. Breaking through the postwar coverup of Nazi doctors in Germany. Journal of Medical Ethics 17, supplement: 13-16.

Psychological Strategy Board. 1951a. Memorandum for Mr. Barnes: Subject: Memorandum from executive secretary of director's group in response to questionnaire from Tracy Barnes of 11 December, received at 1600 hours. December 17. CK2349305939, U.S. Declassified Documents Online.

---. 1951b. Minutes of meeting held in director's conference room, Central Intelligence Agency. July 2, CIA-RDP80R01731R003400010010-7. https://www.cia.gov/library/readingroom/document/ciardp80r01731r003400010010-7

. 1951c. Minutes of the fifth meeting of the Psychological Strategy Board. PSB M-5. November 15, CIA-RDP80-01065A000500100012-9. https://www.cia.gov/library/readingroom/document/cia-rdp80$\underline{01065 a 000500100012-9}$

. 1951d. National overt propaganda policy guidance for general war. PSD 11/a, November 14, CIA-RDP80R01731R003200010027-1. https://www.cia.gov/library/readingroom/document/ciardp80r01731r003200010027-1

. 1951e. New functional statements and table of organization for the staff of the Psychological Strategy Board. September 11.

CK2349291067. U.S. Declassified Documents Online.

. 1951f. Plan for conducting psychological operations during general hostilities. PSB 8-a. November 13, CIA-RDP80R01731R0032000100217. https://www.cia.gov/library/readingroom/document/ciardp80r01731r003200010021-7

---. 1951g. Psychological operations plan for Soviet orbit escapees Phase A, [code name Engross]. December 20, CIA-RDP8001065A000200050044-3. https://www.cia.gov/library/readingroom/document/cia-rdp8001065a000200050044-3 
. 1951h. Psychological Strategy Board agenda and staff. August 13, CIA-RDP80R01731R003400010015-2.

https://www.cia.gov/library/readingroom/document/ciardp80r01731r003400010015-2

. 1951i. Psychological Strategy Board minutes. August 13, CIARDP80R01731R003300160014-8.

https://www.cia.gov/library/readingroom/document/ciardp80r01731r003300160014-8

. 1951j. Role of the Psychological Strategy Board under the 4/4/51 directive. September 28, CIA-RDP80R01731R003200010003-7. https://www.cia.gov/library/readingroom/document/ciardp80r01731r003200010003-7

---. 1951k. Tentative agenda: Fourth meeting of the Psychological Strategy Board. October 25, CIA-RDP80-01065A000500100009-3. https://www.cia.gov/library/readingroom/document/cia-rdp80$\underline{01065 a 000500100009-3}$

. 1952a. Memorandum for Mr. James Lay Jr. Executive secretary of the National Security Council subject: Thermonuclear bomb tests. April 29, CK2349238996. U.S. Declassified Documents Online.

- 1952b. Minutes of Psychological Strategy Board Staff meeting. PSB Quarterly Report to NSC. September 17, CK2349255927. U.S. Declassified Documents Online.

.1952c. Minutes of the ninth meeting of the Psychological Strategy Board. PSB M-9. January 31, CIA-RDP80R01731R003300430021-0. https://www.cia.gov/library/readingroom/document/ciardp80r01731r003300430021-0

. 1952d. Minutes of the eleventh meeting of the Psychological Strategy Board. PSB M-11. April 3, CIA-RDP80R01731R003300160012-0. https://www.cia.gov/library/readingroom/document/ciardp80r01731r003300160012-0 
Board. PSB M-15. September 11, CIA-RDP80R01731R003300430014-8. https://www.cia.gov/library/readingroom/document/ciardp80r01731r003300430014-8

. 1952f. Program of psychological preparation for Stalin's passing from power. November 1, CIA-RDP80R01731R003200040020-5. https://www.cia.gov/library/readingroom/document/ciardp80r01731r003200040020-5

. 1952g. PSB Acting Director Tracy Barnes discusses with CIA Director General Walter Bedell Smith the disposition of certain government Documents. September 5. CK234932739, U.S. Declassified Documents Online.

.1952h. Report on social science research in Cold War operations. PSB D-32. April 11, CIA-RDP80-01065A000500080005-0. https://www.cia.gov/library/readingroom/document/cia-rdp8001065a000500080005-0

. 1952i. Status report on the national psychological effort and first progress report of the Psychological Strategy Board. August 1, CIARDP80-01065A000500070007-9. https://www.cia.gov/library/readingroom/document/cia-rdp8001065a000500070007-9

---. 1952j. Terms of reference for PSB Weapons Information Guidance Committee (Panel "D"). PSB D-17d/1a. January 31, CIARDP80R01731R003200020021-6. https://www.cia.gov/library/readingroom/document/ciardp80r01731r003200020021-6

. 1953a. Documents returned to the CIA from the PSB (CIA and PSB correspond regarding whereabouts of various government documents. January 27. CK2349309854, U.S. Declassified Documents Online.

. 1953b. Members of PSB panels and agency points of contact. April 28, CIA-RDP80R01731R003300150002-2. https://www.cia.gov/library/readingroom/document/cia- 
rdp80r01731r003300150002-2

. 1953c. Memorandum to: The Honorable Allen w. Dulles, Director of

Central Intelligence. SUBJECT: Exploitation of communist BW charges.

July 7, CIA-RDP80R01731R003300190004-6.

https://www.cia.gov/library/readingroom/document/cia-

rdp80r01731r003300190004-6

. 1953d. Status report on the national psychological effort as of June

30, 1953, and progress report of the Psychological Strategy Board. July 24, CIA-RDP80-01065A000400100004-9.

https://www.cia.gov/library/readingroom/document/cia-rdp80-

01065a000400100004-9

. 1953e. Third report to the director of the Psychological Strategy

Board with regard to implementation of PSB D-14C psychological

operations plan for reduction of communist power in France. March 5, CIA-RDP80-01065A000200120004-9.

https://www.cia.gov/library/readingroom/document/cia-rdp80-

01065a000200120004-9

. n.d. Psychological Strategy Board: Top secret documents. CIARDP80-01065A000100010001-5. Accessed January 15, 2017. https://www.cia.gov/library/readingroom/document/cia-rdp80$\underline{01065 a 000100010001-5}$

Rawnsley, Gary D. 1999. Introduction. In Cold-War propaganda in the 1950s, ed. Gary D. Rawnsley, 1-9. New York: St. Martin's Press.

Research Projects: Memorandum for assistant director(s), security director CIA, chief TSS. 1952. February 15, DOC_0000140395. https://www.cia.gov/library/readingroom/document/research-projects

Reston, James. 1953. Eisenhower shifts strategy advisor: Asks C.D. Jackson to carry psychological board. The New York Times, March 19.

Rose, Benjamin. 1999. Presidentially-mandated strategic psychological warfare policy coordination Under Truman and Eisenhower: The Psychological Strategy Board and the Operations Coordinating Board. 
Thesis. James Madison University.

Ross, Colin. 2006. The C.I.A. doctors: Human rights violations by American psychiatrists. Richardson, TX: Manitou Communications.

Scheflin, Alan W., and Edward M. Opton Jr. 1978. The mind manipulators: A non-fiction account. New York: Paddington Press.

Schramm, Wilbur, Daniel Katz, Willmoore Kendall, and Theodore Vallance. 1953. The nature of psychological warfare. April 23. AD0022478. Operations Research Office, John Hopkins University. http://www.dtic.mil/docs/citations/AD0022478

Senate Committee on Human Resources. Subcommittee on Health and Scientific Research. 1977. Human drug testing by the CIA, 1977: Hearings before the Subcommittee on Scientific Research of the Committee on Human Resources, United States Senate, 95-1, September 20 and 21, 1977. Washington, DC: Government Printing Office. https://archive.org/stream/US-Government-MedicalExperimentation-On-Humans/human-drug-testing\#page/n0/mode/2up

Senate Committee on Labor and Public Welfare, Subcommittee on Health. 1976. Biomedical and behavioral research, 1975: Joint hearings before the Subcommittee on Health of the Committee on Labor and Public Welfare and the Subcommittee on Administrative Practice and Procedure of the Committee on the Judiciary. 94-1, on human-use experimentation programs of the Department of Defense and Central Intelligence Agency and S. 2515, to amend the Public Health Service Act to establish the President's Commission for the Protection of Human Subjects involved in biomedical and behavioral research, and for other purposes, 94-1, September 10, 12; and November 7, 1975. Washington, DC: Government Printing Office. https://archive.org/details/US-Government-Medical-ExperimentationOn-Humans

Senate Select Committee on Intelligence. 1977. Project MKULTRA, the CIA's program of research in behavioral modification: Joint hearing before the Select Committee on Intelligence and the Subcommittee on Health and Scientific Research of the Committee on Human Resources, 
95-1, August 3. Washington, DC: Government Printing Office. http://www.nytimes.com/packages/pdf/national/13inmate ProjectMKUL TRA.pdf

Senate Select Committee to Study Governmental Operations with Respect to Intelligence Activities. 1976a. Book I, foreign and military intelligence. 94-2, April 26. Washington, DC: Government Printing Office. https://www.intelligence.senate.gov/resources/intelligencerelated-commissions

. 1976b. Book IV, supplementary detailed staff reports on foreign and military intelligence. 94-2, April 26. Washington, DC: Government Printing Office.

https://www.intelligence.senate.gov/resources/intelligence-relatedcommissions

. 1976c. Book VI, supplementary reports on intelligence activities. 942, April 23. Washington, DC: Government Printing Office. https://www.intelligence.senate.gov/resources/intelligence-relatedcommissions

Simmel, George. 1950. The sociology of Georg Simmel. Trans. and edited by Kurt H. Wolff. Glencoe, ILL: Free Press.

Simpson, Christopher. 1994. Science of coercion: Communication research and psychological warfare, 1945-1960. New York: Oxford University Press.

Smith, Dorothy. 1990. The conceptual practices of power: A feminist sociology of knowledge. Boston: Northeastern University Press.

Smith, Walter B. 1952a. Memorandum to: Director Psychological Strategy Board. Subject: Flying saucers. ER-3-2809. DOC_0000015338. https://www.cia.gov/library/readingroom/document/0000015338

. 1952b. Proposed memorandum for the president concerning the Psychological Strategy Board organization and responsibilities. May 6, CIA-RDP80R01731R003300180056-0. 
https://www.cia.gov/library/readingroom/document/ciardp80r01731r003300180056-0

Snow, Nancy. 2009. Rethinking public diplomacy. In Routledge handbook of public diplomacy, edited by Nancy Snow and Philip M. Taylor, 3-11. New York: Routledge.

. 2010. Propaganda, Inc: Selling America's culture to the world. New York: Seven Stories Press.

Society for the Investigation of Human Ecology. 1960. Brainwashing: $A$ guide to the literature. Forest Hills, NY. https://bkofsecrets.files.wordpress.com/2017/02/humanecolbib 1960.p df

Streatfeild, Dominic. 2007. Brainwash: The secret history of mind control. New York: St. Martin's Press.

Taylor, James R., and William Johnson. 1975. Use of volunteers in chemical agent research. Inspector General, Department of the Army, July 21. http://www.governmentattic.org/22docs/ArmyIGBlueGrassVolunteerChe mResearch 1975-2005.pdf

---. 1993. Appendix F. summary of the Department of the Army report: Use of volunteers in chemical agent research: Key elements of the Nuremberg Code of 1947. In Veterans at risk: The health effects of mustard gas and lewisite, 378-381. Washington DC: National Academies Press. http://www.nap.edu/catalog/2058.html

Terms of reference for Ad Hoc Panel L. 1952. July 23. CK2349048619, U.S. Declassified Documents Online.

Theoharis, Athan G. 1984. Researching the intelligence agencies: The problem of covert activities. The Public Historian 6, no. 2: 67-76.

Thomas, Gordon. 1989. Journey into madness: Medical torture and the mind controllers. London: Corgi. 
Thompson, Dennis F. Democratic secrecy. Political Science Quarterly 114, no. 2 (1999): 181-193.

Thornton, Rob. 2015. The changing nature of modern warfare. The RUSI Journal, 160, no. 4: 40-48. DOI: 10.1080/03071847.2015.1079047

Truman, Harry S. 1951. Directive 128 establishing the Psychological Strategy Board. June 20. The American Presidency Project. http://www.presidency.ucsb.edu/ws/?pid $=13808$

. 1952. Memorandum for the chairman, Psychological Strategy Board: Bureau of the Budget, The Psychological Strategy Board: Selected aspects of its concept, organization and operations. June 21, CIARDP80R01731R003300140002-3. https://www.cia.gov/library/readingroom/document/ciardp80r01731r003300140002-3

U.S. Department of State. 1950. Announcement of the establishment of national psychological strategy board. January 14, CIA-RDP8001065A000500120054-1. https://www.cia.gov/library/readingroom/document/cia-rdp8001065a000500120054-1

. 2001. Note on U.S. covert actions. Foreign Relations of the United States, 1964-1968, Volume XII, western Europe. Washington, DC: Government Printing Office. https://history.state.gov/historicaldocuments/frus196468v12/actionsstatement

U.S. Government Accountability Office. 2005. U.S. public diplomacy: Interagency coordination efforts hampered by the lack of a national communication strategy. GAO-05-323, April 4. http://www.gao.gov/products/GAO-05-323

United States Senate. n.d. Senate Select Committee to study governmental operations with respect to intelligence activities. https://www.senate.gov/artandhistory/history/common/investigations/C 


\section{hurchCommittee.htm}

Waggoner, Walter A. 1951. Gray asked by president to head new psychological warfare board. The New York Times, June 9.

Warner, Michael, ed. 1994. The CIA under Harry Truman. PB94928005. History Staff, Center for the Study of Intelligence, Central Intelligence Agency. Springfield, VA: NTIS.

Warner, Michael. 2014. The rise and fall of intelligence: An international security history. Washington, DC: Georgetown University Press.

Watterson, Rodney K. 2014. Whips to walls: Naval discipline from flogging to Progressive-Era reform at Portsmouth prison. Annapolis, MD: Naval Institute Press.

Wilson, Charles E. 1953a. Letter from C.E. Wilson to Allen W. Dulles. February 19, CIA-RDP80B01676R002600130049-9. https://www.cia.gov/library/readingroom/document/ciardp80b01676r002600130049-9

---. 1953b. Memorandum for Secretary of the Army, Navy, Air Force. Subject: Use of human volunteers in experimental research. February 26. In Senate Committee on Labor and Public Welfare, Subcommittee on Health. 1976. Biomedical and behavioral research, 1975: Joint hearings before the Subcommittee on Health of the Committee on Labor and Public Welfare and the Subcommittee on Administrative Practice and Procedure of the Committee on the Judiciary. 94-1, September 10, 12; and November 7, 1975. Washington, DC: Government Printing Office. https://archive.org/details/US-Government-Medical-ExperimentationOn-Humans

Wise, David, and Thomas B. Ross. 1964. The invisible government. New York: Random House.

Wisner, Frank. 1951. Memorandum to the deputy director: Recommendations to accompany magnitude paper. April 23, CIARDP80R01731R001100100008-5. 
https://www.cia.gov/library/readingroom/document/ciardp80r01731r001100100008-5

. 1952. Proposed European trip (sanitized) of the Psychological Strategy Board staff. April 2, CIA-RDP80R01731R003300180006-5. https://www.cia.gov/library/readingroom/document/ciardp80r01731r003300180006-5

Wolfe, Earl William. 2000. The Psychological Strategy Board: An effort by the Truman administration to provide coordination to psychological warfare operations in the early Cold War period 1951-1953. Thesis. University of Tulsa. 
1 Such as the "RDB Advisory Group, HumRRO, Office of the Chief of Psychological Warfare (Army), Human Resources Research Institute (Army)" (Psychological Strategy Board 1953d).

2 Psychological warfare is closely aligned with propaganda. For example, Linebarger $(1954,25)$ describes psychological warfare as "in the broad sense, consists of the application of the parts of the science called psychology to the conduct of war; in the narrow sense, psychological warfare comprises the use of propaganda against an enemy, together with such military operational measures as may supplement the propaganda." Since "World War II, U.S. military and NATO manuals have typically defined 'psychological warfare' or 'psychological operations' as tactics as varied as propaganda, covert operations, guerrilla warfare, and, more recently, public diplomacy" (Simpson 1994, 11). For other definitions, see Institute for Propaganda Analysis (1937) and Goldman and Maret (2016).

3 See National Security Act of 1947, sec. 201(a) and (b); the Establishment consisted of the Department of the Army, Navy, Air Forces, along with the National Security Council, Central Intelligence Agency, National Resources Security Board, Joint Chief of Staff, and other bodies.

4 A memo from CIA Deputy Director/Intelligence Loftus E. Becker (1952) to the DDCI advises that CIA "must insist upon the excision" of statistics in the "Loomis report." Further, Becker advises that Loomis' recommendations that the PSB be given authority by the NSC to coordinate government-wide "all basic social science research being carried an for Governmental purpose whether inside or outside the Government." Henry Loomis, a PSB Staff Consultant, is identified in the minutes of the 15th meeting as the author of Report on social science research in Cold War operations (Psychological Strategy Board 1952h; also see Simpson 1994 and Price 2016). One academic figure, philosopher Sidney Hook, appears to have corresponded with Gordon Gray. See the CREST database for letters.

5 Due to secrecy, we are left with a sparse understanding of PSB's involvement with planning "overt propaganda" during "general war" (Psychological Strategy Board 1951c,1951d) and "general hostilities" (Psychological Strategy Board 1951c, 1951f); PSB's involvement with the U.S. State Department's Voice of America (VOA) broadcasting system (Memorandum For: Chief, PY, 1952; Psychological Strategy Board 1952i) and operations pertaining to "literature as an anti-Communist weapon" (Department of Defense 1952a) are also little discussed in the scholarly literature. In part, secrecy contributed to the concealment of PSB's Working Committee in addressing "germ warfare" allegations (Psychological Strategy Board 1952b; Central Intelligence Agency n.d.), its role in the "exploitation of Communist BW charges" during the Korean War (Craig 1953), and the discrediting of the Needham committee or the International Scientific Commission for the Investigation of the Facts Concerning Bacterial Warfare in Korea and China and its Report of the International Scientific Commission for the investigation of the facts concerning bacterial warfare in Korea and China (Psychological Strategy Board 1953c; Endicott and Hagerman 1998; Buchanan 2001). Also muddy is the PSB's involvement with "special measures to deal with 'brain washing'" of repatriated, "indoctrinated" servicemen who confessed to allegations the United States deployed biological weapons during the Korean War (Psychological Strategy Board 1953c).

6 CIA's intelligence program between journalists, newspapers, and broadcasting companies. See Carl Bernstein, "CIA and the media," Rolling Stone October 20, 1977, http://www.carlbernstein.com/magazine cia and media.php; also see the Church Committee hearings, vol. 1.

7 There is some evidence that PSB did have a relationship with the Foundation as evidenced by C.D. Jackson's response to Nelson Rockefeller on International Information programs. The memo was reviewed by acting director of the PSB, George Morgan (Memorandum For 1953). Long after the PSB's demise, Psychological aspects of United States strategy panel report, a secret "group study" written by twelve contributors requested by Nelson Rockefeller to 
participate, concluded that "psychological strategy is not a separate course of action but an integral component of all our policies and programs" (Anderson 1955). Among the twelve Panel members were C.D. Jackson (who wears his Time, Inc. hat for the Panel) and Henry Kissinger. Full chapters by the participants appear in a more formal 223 page volume, found in CREST at: https://www.cia.gov/library/readingroom/docs/CIA-RDP86B00269R000300120001-4.pdf

8 Clandestine is defined as an "operation sponsored or conducted by governmental departments or agencies in such a way as to assure secrecy or concealment"; clandestine is also defined as "any activity that is designed not to be detected by a local security service; a concealed, hidden, secret, or surreptitious operation conducted without the knowledge of anyone but the organization conducting the operation or investigation" (Goldman and Maret 2016). For definitions on covert operations, see the Department of Defense (DOD) Dictionary of military terms at http://www.dtic.mil/doctrine/dod dictionary/data/c/47.html

9 That is, Hourcle (1993) uses the "secret island" metaphor to explain those individuals with security clearances that have access to classified national security information. Hourcle explains this privilege creates "insular 'island-like' societies. A sea of requirements, including security clearances and 'need to know' restrictions, isolate people outside the 'secret island.'" Hourcle is important to my argument, but here the island metaphor goes deeper to include rogue elements who bypass official information policies in making decisions about the preservation of classified information.

$10 \mathrm{~A}$ redacted version of this memo is found in CIA's CREST at https://www.cia.gov/library/readingroom/docs/CIA-RDP80-01065A000500140033-2.pdf

11 Barnes $(1982,668)$ notes that the OCB "gave formal approval to covert activities and its regular members were under-secretaries, underlining the importance with which these operations were viewed."

12 One might speculate too that "troll armies" (Benedictus 2016) and "micro-targeting" of voters in order to shape opinions in the 2016 election (Clarke 2017) have their roots in the psychological war between Cold War powers.

13 Such as the contemporary NSC's Strategic Communication Policy Coordinating Committee that was "charged with coordinating interagency activities to ensure that all agencies work together and with the White House to develop and disseminate the President's message to foreign audiences. As part of this effort, the group drafted a national communication strategy" (U.S. Government Accountability Office 2005, 10). The Committee "terminated with the departure of the then Under Secretary for Public Diplomacy and Public Affairs, who co-chaired the group, and the onset of the war in Iraq U.S. Government Accountability Office 2005, 10). In 2006, the Policy Coordinating Committee for Public Diplomacy and Strategic Communication (PCC) was established "as the principal interagency coordination body for U.S. government communications with foreign publics" (Nakamura and Weed 2009).

More recently, the Countering disinformation and propaganda act (S.3274, included in the 2017 National Defense Authorization Act Conference Report) was signed into law by President Obama on December 23, 2016. Countering Disinformation establishes the Global Engagement Center within the U.S. State Department; furthermore, the Act "will improve the ability of the United States to counter foreign propaganda and disinformation from our enemies by establishing an interagency center housed at the State Department to coordinate and synchronize counterpropaganda efforts throughout the U.S. government. To support these efforts, the bill also creates a grant program for NGOs, think tanks, civil society and other experts outside government who are engaged in counter-propaganda related work" (press release, Sen. Rob Portman, R-OH, https://www.portman.senate.gov/public/index.cfm/2016/12/president-signsportman-murphy-counter-propaganda-bill-into-law). 
Maret: Murky Projects and Uneven Information Policies

14 And covert influence campaigns, "where you take information and wash it through third parties - DC Leaks, Wikileaks and other for a - and push this information out not to learn about a society - that's espionage - but to change the society"; see Michael Hayden (2017). "Who hacked the DNC," Cyberwar, October 10 (s02e02).

15 For definitions, see the Dictionary of military and associated terms at http://www.dtic.mil/doctrine/dod_dictionary/ and Goldman and Maret (2016). Also see Thornton (2015) and research of the period, for example, Schramm (1953).

16 In 2015, Government Attic (2016) submitted a Freedom of Information Act request to the National Archives and Records Administration (NARA) for an inventory of records "withheld in full" in the John F. Kennedy Assassination Records Collection. The President John F. Kennedy Assassination Records Collection Act of 1992 mandated that "all assassination-related material be housed in a single collection at NARA." See https://www.archives.gov/research/jfk/ NARA will release Committee records in October, 2017 but in anticipation of the release, in February of 2017, I submitted a FOIA request for Dr. Sidney Gottlieb's October testimony to the Committee in the hope of learning more about the PSB and BLUEBIRD, ARTICHOKE, and MKULTRA. CIA projects release of this information in 2018.

17 In 1995, CIA, the National Archives, and presidential libraries "proposed to the intelligence and classifying community a cooperative interagency plan called the Remote Archive Capture (RAC) project. The purpose was to digitize all classified Presidential papers so that the scanned images could be brought to Washington, D.C for a declassification review by the equity-holding agencies." See https://www.archives.gov/presidential-libraries/declassification/rac.html

18 Such as techniques outlined in the CIA's 1963 KUBARK counterintelligence interrogation manual (Blanton and Kornbluh 2014; McCoy 2007; Price 2016).

19 This switch from State to the NSC is substantiated by the Church Committee, who wrote that by "supplanting an earlier board created in the Department of State under Assistant Secretary Edward W. Barrett, the new panel attempted to determine the psychological objectives of the United States and coordinated and evaluated the work of operating psychological warfare agencies" (Senate Select Committee to Study Governmental Operations with Respect to Intelligence Activities 1976c, 250).

20 NSC 10/2 "directed CIA to conduct 'covert' rather than merely 'psychological" operations,' defining them as all activities 'which are conducted or sponsored by this Government against hostile foreign states or groups or in support of friendly foreign states or groups but which are so planned and executed that any US Government responsibility for them is not evident to unauthorized persons and that if uncovered the US Government can plausibly disclaim any responsibility for them.' The type of clandestine activities enumerated under the new directive included: 'propaganda; economic warfare; preventive direct action, including sabotage, demolition and evacuation measures; subversion against hostile states, including assistance to underground resistance movements, guerrillas and refugee liberations [sic] groups, and support of indigenous anti-Communist elements in threatened countries of the free world. Such operations should not include armed conflict by recognized military forces, espionage, counterespionage, and cover and deception for military operations"' (U.S. State Department 2001). Also see the CIA memo titled Coordination and policy approval of covert operations January 4, 1967, DOC 0000790232 at https://www.cia.gov/library/readingroom/document/coordinationand-policy-approval-covert-operations

21 A partial list, the PSB Task Panels include: A, which "reviewed US psychological programmes if the negotiation to end the Korean War were successful or if they broke down (Lucas 1996, 
Secrecy and Society, Vol. 1, No. 2 [2018], Art. 6

289), B (inventory of Cold War weapons), C, responsible for Cold War psychological planning, D (Psychological Strategy Board 1952j), E, F, H, Panel I (Southeast Asia), Panel J (economic security programs concerned with the Soviet orbit), Ad Hoc Panel L ("Psychological Implications of Thermonuclear Tests") and Panel M (doctrinal warfare) (Psychological Strategy Board 1953b).

22 Gray was Assistant Secretary and later Secretary of the Army. In 1950, he became president of the University of North Carolina. See the Eisenhower Presidential Library finding aid on Gray at https://www.eisenhower.archives.gov/research/finding_aids/g.html

Other PSB directors include Gen. Walter Bedell Smith "chairman of the PSB. The military adviser was Admiral Leslie Stevens. Gordon Gray was chosen to be director of the staff" (Montague 1992, 205). Subsequent PSB directors are Raymond B. Allen ("Dr. Allen Accepts Strategy Position" 1951), Adm. Alan G. Kirk ("Admiral Kirk's New Post" 1952), and C.D. Jackson, director in 1953 (Reston 1953). I couldn't locate records that substantiated Jackson's appointment.

23 In select Board minutes, (e.g. 10th) PSB staff member names are redacted, as are CIA participants. In 2016, I submitted a successful MDR and received the PSB's Biographical Register for 1952 and 1953. In this article, I attempted to match names on the Register against numerous PSB and CIA documents. See https://bkofsecrets. files.wordpress.com/2017/02/bioregisterpsb 1952.pdf and https://bkofsecrets.files.wordpress.com/2017/02/bioregisterpsb 1953.pdf

24 Membership of the President's Commission included former PSB director Gordon Gray, Gen. Robert Cutler, and C.D. Jackson, former OSS, publisher of Fortune, and speechwriter for Dwight D. Eisenhower. Jackson was also an influential member of the PSB's successor, the Operations Coordinating Board. See Cook (1984) and John Allen Stern, C.D. Jackson: Cold War propagandist for democracy and globalism (University Press of America, 2012).

25 Previous to its dissolution, C.D. Jackson (1953) recommended several projects to the PSB that included a "free world congress" where "representative citizens groups from all free nations would be present...the theme would be the true Peace Plan, as expressed in Eisenhower's "highway to peace." Other projects included urging the Soviet Union to return all World War II prisoners, "introducing irrefutable scientific evidence of the colossal falsehood of the germ warfare charges" in Korea, and "calling upon the Soviets to lift the ban on the two way flow of newspapers, periodicals, and books" (Jackson 1953).

26 A search of CREST indicates that Morgan was acting director of PSB at least until September, 1953, around the time of the Board was abolished. Also see note 22.

27 As proposed by Lt. Geiger (Air Force) in August 1952, and reported in a redacted memo from the Operations Coordination Branch, Psychological Staff Division to the PSB, "This type of warfare is "primarily intended as a means of undermine collective emotional stability" (Central Intelligence Agency 1952c). The memo expresses the refinement of "definition of techniques" and issued a call for the "services of a psychiatrist or clinical psychologist, a cultural anthropologist, and a psychological warfare operator must be employed in a combined effort." The Psychological Staff Division was the "responsible office for the conduct for NSC 10/2" between the PSB and CIA (Central Intelligence Agency 1952b).

28 Executive Order 13526 governs the declassification of nonexempt "historically valuable records" 25 years or older; systematic declassification is required for those records exempted from automatic declassification and discretionary declassification is "conducted when the public interest in disclosure outweighs the need for continued classification or when an agency determines the information no longer requires protection and can be declassified earlier" (ISOO 
2016). The Interagency Security Classification Appeals Panel or ISCAP, "acts as the appellate authority for classification and declassification decisions" when specific records are requested by the public. This is termed Mandatory Declassification Review or MDR" (ISOO 2016).

29 See the National Archives and Records Administration (NARA), which began to release previously classified documents and audio in July, 2017, https://www.archives.gov/press/pressreleases/2017/nr17-68

30 Correspondence with Mr. Randy Sowell, archivist, Truman Presidential Library. Also see CIA $v$. Sims 471 U.S. 159 (1985), https://supreme.justia.com/cases/federal/us/471/159/ in which the Supreme Court ruled that CIA could withhold information via FOIA Exemption 3 concerning government-sponsored programs such as MKULTRA. The justification for this ruling was that information could reveal intelligence sources specifically protected from disclosure under the National Security Act of 1947.

31 When asked by the Select Committee about the regularity of the procedure by which he authorized Dr. Gottlieb to destroy the MKULTRA records, Helms responded: "Well, that's hard to say whether it would be part of the regular procedure or not, because the record destruction program is conducted according to a certain pattern. There's a regular record destruction pattern in the Agency monitored by certain people and done a certain way. So that anything outside of that, I suppose, would have been unusual. In other words, there were documents being destroyed because somebody had raised this specific issue rather than because they were encompassed in the regular records destruction program. So I think the answer to your question is probably yes" (Senate Select Committee to Study Governmental Operations with Respect to Intelligence Activities 1976a, 404; Helms testimony, 9/11/75, 6).

32 The burning of ninety-two interrogation videotapes in 2005 is a more recent example of this type of destruction policy. The destruction of the tapes was authorized by Jose Rodriguez Jr., head of CIA's Directorate of Operations. The U.S. Department of Justice conducted a three year investigation, but did not press criminal charges (Markon 2010). This destruction, along with the return of all copies of the classified report on torture to the Senate Select Committee on Intelligence (and hence making the report not available through FOIA), is the dark side of information policy - and what Friedrich (1972) classifies as "disfunctional" secrecy.

33 The Memo is a redacted 11 page document that includes additional memos of various dates and subjects. It is assigned Document Number/ESDN of CIA-RDP83-01042R000800010005-9. The same Document Number/ESDN is listed on the "Senate Select Committee Request (Artichoke/Bluebird). See https://www.cia.gov/library/readingroom/document/cia-rdp8301042r000800010005-9

34 Lashbrook was a DOD chemist and a major figure in the Frank Olson suicide (Albarelli 2010).

35 See Adm. Stansfield Turner's testimony (Senate Select Committee on Intelligence 1977, 8-51).

36 Turner's inventory comes to 74, not 86 institutions.

37 I sent several emails to Black Vault asking the origin of these documents. As of press time, I hadn't received a reply.

38 There remain questions as to the participation of OPC staff such as Wisner (Asst. Director for Policy Coordination, 1948-1951) in the three programs, as well as the relationship between OPC and CIA internal divisions involved with programmatic R\&D (e.g., Office of Scientific Intelligence, Inspection and Security Office, and Office of Security), and their relationship to the PSB. 
Secrecy and Society, Vol. 1, No. 2 [2018], Art. 6

39 Col. Edwards became the civilian Director of CIA's Office of Security in 1953. See CIA-RDP7804718A000200110041-4, https://www.cia.gov/library/readingroom/document/cia-rdp7804718a000200110041-4

40 Marks $(1979,108)$ recounts Earman's investigation of safehouses used during the MKULTRA program. However, in light of the BLUEBIRD briefing, there are questions as to what knowledge Earman deliberately omitted and chose not to share regarding predecessor projects in his IG report on MKULTRA.

41 I obtained this document under FOIA from CIA, February, 2017.

42 We know the IAC regularly cited the Third Agency Rule "as a basis for refusing to give intelligence to CIA" (Keane and Warner 2007, 30). It is important to ask here if the PSB was the subject to the Rule by the very agencies in which it was charged to coordinate psychological warfare activities.

43 The Church Committee described Chatter as beginning in the fall of 1947 and "responding to reports of 'amazing results' achieved by the Soviets in using 'truth drugs,' the program focused on the identification and testing of such drugs for use in interrogations and in the recruitment of agents. The research included laboratory experiments on animals and human subjects involving Anabasis aphylla, scopolamine, and mescaline in order to determine their speechinducing qualities. Overseas experiments were conducted as part of the project. The project expanded substantially during the Korean War, and ended shortly after the war, in 1953" (Senate Select Committee to Study Governmental Operations with Respect to Intelligence Activities 1976a, 387). There is some evidence LSD was also tested; see Lysergic acid diethyl amide (LSD-25): A clinical-psychological study by Lt. Charles Savage, USN, that Black Vault obtained under FOIA: http://www.theblackvault.com/documents/biologicalweapons/chatter/navychatter.pdf

44 We may never know if the PSB' was aware of Secretary of Defense Charles E. Wilson's (1953b) memorandum based on the 1947 Nuremberg Code. The Wilson memo offered guidance to researchers as to "legal capacity [of subjects] to give consent" and provided an ethical foundation for research and human experimentation in the areas of atomic, biological, and chemical warfare.

45 The Society was founded in 1954 by Harold G. Wolff, MD, "an expert on migraine headaches and pain," who, along with Lawrence Hinkle, conducted brainwashing studies for CIA (Marks 1979, 94; Price 1998).

46 The quote cited by the Committee is from a CIA memorandum to the Select Committee, "Behavioral drugs and testing," 2/11/75, Senate Select Committee to Study Governmental Operations with Respect to Intelligence Activities 1976a, 388.

47 See Central Intelligence Agency (1954). Former CIA agent Miles Copeland stated in a 1986 interview published in Rolling Stone that "the congressional subcommittee which went into this sort of thing got only the barest glimpse." I believe Copeland here refers to the Church Committee's Alleged assassination plots involving foreign leaders: Select Committee to Study Governmental Operations with Respect to Intelligence, interim report dated November 20, 1975. https://www.rollingstone.com/culture/features/secret-agent-man-19860116

48 Harold E. Stassen, Foreign Operations Administration, U.S. Department of State. See https://history.state.gov/departmenthistory/people/stassen-harold-e

49 The Dulles' (1953) memo portrays the Wilson letter in a more direct way, stating "charge the 
enemy with using United States' prisoners of war for propaganda purposes and demand that U.S. prisoners of war who have confessed dropping bacteriological warfare bombs in Korea be brought into neutral territory for permanent internment until the end of hostilities."

50 Further research is needed on secret CIA-Chemical Corps' joint research on the effects of LSD (Taylor and Johnson 1975; Advisory Committee on Human Experimentation 1995, 780-4; Moreno 1996).

51 See various U.S. Chemical Corps documents (e.g., 1955) that pose questions as to the veracity of such a relationship: https://rockymountainarsenalarchive.wordpress.com/2011/07/09/summarymajorevents/

52 It is not clear from the hearings if these tests were part of MKULTRA or a project titled MKACTION, of which very little is found in CREST.

53 Data generated from the BLUEBIRD, ARTICHOKE, and MKULTRA programs was, in many cases, published in the scholarly literature. For example, a bibliography compiled by the Society for the Investigation of Human Ecology (1960) on the subject of brainwashing, cites books, reports, and the journal and popular magazine literature from 1949 through 1960. A report titled Experimental Studies of Sensory Deprivation and Social Isolation, prepared for the Chief of Research and Development, Department of the Army, also cites research conducted during the 1950s-1960s by researchers associated with the trifecta BLUEBIRD, ARTICHOKE, and MKULTRA (Myers, et al 1966). These publications appear to verify testimony of Sidney Gottlieb that researchers involved in CIA-funded projects published their research in the open scholarly literature. Gottlieb stated that "to my recollection, in every case, the results of the related research were published. I should add 'where appropriate.' I cannot testify that everybody published everything they did" (Senate Committee on Human Resources 1977, 171). It is not clear if the PSB was aware of origins and/or publication of research produced from the three programs.

$54 \mathrm{DD} / \mathrm{P}$ is the Deputy Directorate for Plans.

55 A program to "identify drugs with behavioral effects" (Senate Committee on Human Resources $1977,151,160)$.

56 Described as an Army and CIA project (Senate Committee on Human Resources 1977, 127, 149). 